\title{
Disintegration, modularity and entry mode choice: Mirroring technical and organizational architectures in business functions offshoring
}

Article

Accepted Version

Creative Commons: Attribution-Noncommercial-No Derivative Works 4.0

Narula, R., Massini, S. and Elia, S. (2019) Disintegration, modularity and entry mode choice: Mirroring technical and organizational architectures in business functions offshoring. Journal of Business Research, 103. pp. 417-431. ISSN 01482963 doi: https://doi.org/10.1016/j.jbusres.2017.11.034 Available at https://centaur.reading.ac.uk/74135/

It is advisable to refer to the publisher's version if you intend to cite from the work. See Guidance on citing.

To link to this article DOI: http://dx.doi.org/10.1016/j.jbusres.2017.11.034

Publisher: Elsevier

All outputs in CentAUR are protected by Intellectual Property Rights law, including copyright law. Copyright and IPR is retained by the creators or other copyright holders. Terms and conditions for use of this material are defined in the End User Agreement. 


\section{CentAUR}

Central Archive at the University of Reading

Reading's research outputs online 
Disintegration, Modularity and entry mode choice:

Mirroring technical and organizational architectures in business functions offshoring

\begin{abstract}
We study the relationship between modularity and entry mode choice in the context of business functions offshoring. We define the degree of modularity of an activity as technical architecture (whether it can be detached from the rest of the value chain without loss of synergies). We refer to the entry mode chosen as organizational architecture (whether a captive solution, a partnership or outsourcing). We propose that the selection of entry mode should reflect the alignment of the technical and organizational architectures: that is, they need to be 'mirrored'. Modular activities are more likely to be outsourced, as modularity decreases transaction costs and knowledge leakages risks, while not-modular activities reflect captive entry modes. Based on the analysis of 486 business function offshoring initiatives, we also argue that firms can "break" the mirror as the entry choice is contingent upon the level of disintegration of the value chain and the offshoring experience of the firms.
\end{abstract}

\title{
Keyword:
}

Entry mode, Modularity, Business Functions Offshoring, Outsourcing, Technical and Organizational Architectures, Mirroring Hypothesis. 


\section{Introduction}

The offshoring of business functions is a growing trend where firms globally source whitecollar work, including R\&D, technical and administrative activities (Lewin and Peeters, 2006; Kenney, Massini and Murtha, 2009; Albertoni and Elia, 2014, Anderson and Pereira 2017, Pereira, Munjal and Ishizaka 2017). Improvements in information and communication technologies have dramatically decreased the transaction and coordination costs of managing cross-border activities, thus enabling firms to fragment and disintegrate their value chain across countries in order to access specific resources such as qualified personnel, knowledge and new technologies (Manning, Massini and Lewin, 2008; Lewin, Massini and Peeters, 2009; Elia, Caniato, Luzzini and Piscitello, 2014; Gooris and Peeters, 2016).

However, although fragmenting a value chain may seem straightforward in principle, disintegration is not so simple in practice (Baldwin \& Clark, 1997; Cacciatori \& Jacobides, 2005; Kotabe, Parente \& Murray, 2007; Langlois \& Robertson, 1992; Parente, Baack \& Hahn, 2011). Indeed, the extent to which a firm can decrease transaction and coordination costs, knowledge leakages risks and operational efforts associated with value chain disintegration depends also on the level of independence among its components, i.e. the modularity of its architecture (Cabigiosu and Camuffo, 2012).

The notion of modularity has been increasingly discussed in the innovation and management literature (Baldwin \& Clark, 1997, 2000 and 2006; Brusoni \& Prencipe, 2001; Brusoni, Prencipe \& Pavitt, 2001; Cabigiosu and Camuffo, 2012; Furlan, Cabigiosu and Camuffo, 2014; Langlois, 2002; Langlois \& Robertson, 1992; Lew, Sinkovics, Yamin and Khan, 2016). Modularity refers to the partitioning a product or a system into discrete, independent and self-contained modules, without any loss of synergies and complementarities among the individual components (Baldwin and Clark, 2000; Brusoni \& Prencipe, 2001; Campagnolo and Camuffo, 2010). Specifically, this literature distinguishes between modularity at two levels. First, at the level of the product, i.e., modularity as a property, or component modularity, that is to say the modularity of the technical architecture. Not 
all products are easily divided into sub-units: systems that are highly interdependent are difficult to 'slice' into distinct modules. Second, there is also modularity at the organizational level. Organizational modularity refers to the extent to which the tasks are implemented across administrative units within an organization (MacDuffie, 2013; Furlan, Cabigiosu and Camuffo, 2014). For instance, in a packaging company, the sales unit is relatively easy to separate organizationally from manufacturing, while marketing and product development are highly interdependent, and organizationally these activities are best undertaken by an integrated team.

Scholars have argued that, from a conceptual point of view, these two dimensions of modularity are related, in that the organizational architecture of a project should reflect its technical architecture (and vice-versa) - the so-called "mirroring hypothesis" (Colfer \& Baldwin, 2016). Activities that are highly integrated, i.e. that require constant and intense communication between specialists or that involve a fairly high degree of tacit knowledge, are more difficult to 'slice' from an organizational perspective. That is, they require considerable and intense interaction between organizational units and are more difficult to organizationally modularise. Activities characterised by modular technical architecture, i.e. that do not require constant interaction or that are fairly easily codified, can be designed more efficiently by modular organizations, and can in principle be undertaken by separated organizations (Narula 2001; Brusoni, 2005). Offshoring requires an alignment of organizational and technical architecture, since each type of architecture 'reflects' the modularity of the other.

In our paper, we intend to explain what are the dynamics associated with the decision of when to offshore, and how this is most effectively achieved, in the context of business services offshoring. Utilising the mirroring hypothesis, we focus on whether an activity being offshored should be organized internally within a firm, or alternatively, should be organized outside the boundaries of the firm (that is, outsourced).

The choice between internalization or externalization (outsourcing) decisions corresponds to the entry mode choice in the international business literature, which is probably the most 
extensively studied and debated decision that MNCs make when offshoring (Hätönen and Eriksson, 2009; Pereira and Malik, 2015). However, there is still need for further analysis on the reasons why firms choose to 'buy' instead of 'make', by taking into account the interdependencies within the value chain (Brouthers, 2013; Hennart and Slangen, 2014). Our paper addresses this lacuna by inquiring: under what conditions is it possible to apply the mirroring hypothesis to explain the entry mode choice of firms disintegrating their value chain through business function offshoring?

We bridge the modularity and mirroring hypothesis literature with the international business literature and, in doing so, provide a contribution to both the mirroring hypothesis and the international business literature. Specifically, we argue that the make-or-buy choice can be conceived as a decision of the extent to which a firm decides to align the technical architecture of an activity (which in turn depends on its modularity) with the organizational architecture of the offshoring initiative involving that activity. In order to support this perspective, we draw from both Transaction Cost Economics (Williamson, 1985) and the Resource Based View and Knowledge Based Theory (see, for instance, Barney, 1991; Marengo \& Dosi, 2005; Nickerson \& Zenger, 2004), which both suggest that interdependent (i.e., not modular) activities should be organized within a single firm rather than across firms. In doing so, they implicitly point to the need to design the organizational architecture of an activity according to its technical architecture. For instance, an external (outsourcing) solution is more appropriate in the case of a modular activity because it is less affected by transaction costs and knowledge leakages risks. Hence, consistent with the mirroring hypothesis (Baldwin, 2008; Baldwin \& Clark, 2000; Langlois, 2002; Teece, 1996), we argue that business functions that present a modular technical architecture (i.e. a low risk of loss of synergies in case of offshoring) will show higher probability to select a governance mode based on an outsourcing solution.

We develop this argument further and propose that the extent to which companies comply with the mirroring hypothesis is contingent upon the level of disintegration of their value chain. Specifically, we distinguish the traditional separation of the value chain among different business 
functions from a more intensive level of disintegration, i.e. the "functional fine-slicing", which refers to the possibility of subdividing each business function into smaller, possibly less complex and more homogenous tasks. We claim that the reintegration costs (i.e. the efforts required to reintegrate the modules into the system) are potentially lower when the company offshores single tasks of a function rather than the whole function. Indeed, in the former case, the firm will have to reintegrate single activities which share a common platform (in terms of routines, managerial practices etc.) as they belong to the same function, while in the latter case, the firm will have to reconnect the offshore function with the inshore functions, thus reconciling different and heterogeneous platforms. As a consequence, the mirroring hypothesis is more likely to hold when the disintegration of the value chain occurs with - rather than without - functional fine-slicing.

Finally, we propose that the mirroring hypothesis in the entry mode choice is contingent also on firms' experience. Companies with previous offshoring experience are likely to have already experienced the challenges arising from a mismatch between the two.

We test our conjectures on data from 486 offshoring initiatives provided by the Offshoring Research Network (ORN). Our analysis supports the mirroring hypothesis, suggesting that modular (non-modular) activities are more likely to be offshored through an outsourcing (captive) solution, especially in case of functional fine-slicing and when firms are experienced.

\section{Theoretical framework and hypotheses development}

\section{Technical and organizational modularity in business functions}

The relocation of business activities to offshore locations involves the reconfiguration of some activities in the value chain that are currently performed domestically. Disintegration is easier in the case of modular products and systems, i.e., when it is possible to partition a product or a system into discrete and self-contained modules. Partitioning an activity is strictly related to the ability of the firm to fragment, "mix and match", and recompose the knowledge that is needed for 
that activity, without losing critical information (Brusoni \& Prencipe, 2001). In other words, modularization requires the knowledge boundaries of the firm to stretch beyond its production boundaries (Asmussen, Larsen \& Pedersen, 2016). In fact, even if an activity is fragmented into smaller components, each associated to specialized knowledge, the firm must be able to act as a system integrator by orchestrating the network of modules, recomposing the knowledge modules and guaranteeing the overall consistency of the product/service (Brusoni, 2005; Brusoni \& Prencipe, 2001; Brusoni, Prencipe \& Pavitt, 2001; Cantwell \& Santangelo, 2000). This task becomes particularly challenging when the individual components require a high degree of interconnectivity across a number of people, sectors, technologies and products (Granstrand, Patel $\&$ Pavitt, 1997), i.e. when they need frequent connections such as regular, efficient and intensive knowledge flows, e.g. through systematic face-to-face meetings among scientists, engineers and managers in different units (Narula, 2014). Therefore, the modularity of an activity depends on the extent to which the single modules are independent, relatively generic, and not co-specialized, i.e. they can be separated without loss of synergies and complementarities.

This is especially true for business functions, which are as organizational departments - such as marketing, finance and accounting, human resources, $R \& D$ - that have idiosyncratic characteristics built around specific skills and occupational specializations. While the modularity of manufacturing activities has been largely analyzed within the industrial and management literature (e.g., Baldwin \& Clark, 1997, 2000 and 2006; Gawer, \& Phillips, 2013; Langlois, 2002; Langlois \& Robertson, 1992), there is only limited research on modularity of business functions, mainly in the context of knowledge intensive IT services (e.g., Miozzo \& Grimshaw, 2005). Business functions are generally subject to a larger degree of intangibility in their output, compared to manufacturing physical products. This leads to increased uncertainty and opportunistic behavior by external actors, and therefore, stronger challenges for managing cross-border transfer (Ashok, Narula \& MartinezNoya, 2014; Miles, 1993; Parida, Wincenta \& Oghazid, 2016). A second peculiar characteristic of business functions is that they are produced and consumed simultaneously, implying that a service 
product can often be identified with the service process itself, unlike manufacturing goods that are consumed after production (Bask, Lipponen, Rajahonka \& Tinnilä, 2010; Voss \& Hsuan, 2009). The simultaneity of production and consumption in business functions implies high probability of unintentional transfers of the knowledge content, which might result in a loss of competitive advantage. Therefore, companies' offshoring knowledge intensive activities must adopt some safeguards measures in order to minimize the possibility of knowledge leakages (Parida, Wincenta \& Oghazid, 2016).

Additionally, the simultaneity of production and consumption in business services requires continuous interfacing between people to share information (Ashok, Narula, \& Martinez-Noya, 2014; Bask, Lipponen, Rajahonka \& Tinnilä, 2010; Voss \& Hsuan, 2009). In particular, knowledgeintensive business functions require firms to act as knowledge brokers who interact with and transform knowledge of their clients and other knowledge holders (Tether \& Tajar, 2008). This implies the need for greater interconnections (Den Hertog, 2000). The interdependencies between various actors are especially important when activities are more intangible and characterized by higher degree of tacitness (Narula, 2001, 2014). In other words, business functions activities are likely to require stronger interconnections than manufacturing activities. Therefore, the modularity of business functions not only requires disintegrating an activity into smaller modules, but also understanding the implications of doing so in terms of organizational architecture of the modularized activities.

The literature has, indeed, identified two distinct dimensions of modularization. Sanchez (1999) distinguishes between the way in which a product or process is decomposed into individual functional components and the ways in which these functional components interact to provide overall functionalities of the system. Brusoni, Prencipe \& Pavitt (2001) define a modular innovation as "a change in the core design concept of a component that does not affect its relationship with the others" and an architectural innovation as "a change in the relationships between a product's components that leaves untouched the core design concepts of components". Cabigiosu and 
Camuffo (2012) and Furlan, Cabigiosu and Camuffo (2014) distinguish between component modularity, which refers to the extent to which a component performs a function and is connected to other components through open standard interfaces, and organizational modularity, which refers to the complexity, intensity and frequency of information sharing between two organizations. Similarly, Brusoni \& Prencipe (2001) distinguish between product modularity and organizational modularization, while MacDuffie (2013) discriminates modularity-as-property from modularization-as-process: in both studies, the former concept identifies the possibility to frame a product, organization or network in different discrete modules, while the latter refers to the way through which these modules are organized based on their level of interdependence. Colfer \& Baldwin (2016) refer to the first dimension of modularity as the technical architecture and to the second one as the organizational architecture. We build on this contribution because it relates more closely to the specific context of our study: business functions and organizational boundaries. In the following paragraphs, we discuss the relationship between these two dimensions of modularity within the context of business functions offshoring by elaborating on the "mirroring hypothesis", i.e. the reasons why and the conditions under which firms align the technical and the organizational architectures of a business function when selecting the entry mode choice(Colfer \& Baldwin, 2016).

\section{Entry mode and mirroring hypothesis: hypotheses development}

When a firm decides to offshore a business function and relocate abroad an activity currently carried out domestically, the selection of the entry mode, i.e. choosing between hierarchy (captive), market (outsourcing) or intermediate (such as alliances and joint ventures) solutions, remains one of the most challenging choices, because this decision might directly affect the performance of the offshoring venture (Brouthers, 2013).

The make-or-buy-or-ally choice is traditionally explained by Transaction Costs Economics (TCE - Coase, 1937; Williamson, 1985). When market transactions are inefficient or non-feasible (e.g. due to asset-specificity, uncertainty, bounded rationality, information asymmetries, distance, 
communication problems and lack of measurable outputs), firms tend to favor internal transactions (offshore in a fully owned, captive operation) rather than to rely on the market (e.g. international outsourcing). In these circumstances, suppliers are prone to opportunistic behavior and firms deploy substantial resources to negotiate and monitor the transaction to make sure that contract requirements are met, and to minimize knowledge leakages. As a consequence, firms are more likely to opt for internal solutions that minimize transactions costs (Williamson, 1975). TCE has been largely employed to explain also the specific entry mode decisions by MNCs (Buckley and Casson, 1976; Hennart, 1988 and 1989; Rugman, 1980 and 1986; Brouthers, 2002). Internalization Theory, in particular, builds on the assumption that firms invest abroad to exploit ownership advantages, which needs to be preserved against competitors. When companies rely on intangible and knowledge-intensive ownership advantages, transaction costs are high for external entry-modes (such as outsourcing), since knowledge leakages erode the advantage (Madhok, 1997; Narula and Martinez-Noya, 2015). In this case, firms are likely to opt for a hierarchical solution. When the ownership advantage depends on knowledge intensive and intangible assets that are less specific, transaction costs are lower and firms are more willing to adopt market solutions such as licensing and outsourcing (Cantwell and Narula, 2001, Buckley et al, 2017). Even within cooperative agreements, equity alliances are preferred over non-equity alliances in knowledge-intensive and intangible activities, as they allow a higher degree of control over the opportunistic behavior of the partner by aligning the incentives of both partners and by creating a high degree of interdependency and a mutual hostage position (Narula and Hagedoorn, 1999; Mudambi and Tallman, 2010; Narula and Martinez-Noya, 2015). Internalization is, therefore, a decision about the degree to which firms collaborate with external companies (through either cooperative agreement or suppliers) (Narula and Verbeke 2015), and the choice of mode by which firms engage much broader than the dichotomous perspective often used by the mainstream IB literature (Benito, Petersen and Welch, 2009; Chang, Chung and Moon, 2013). 
More recently, scholars studying entry mode choice have built upon the Resource Based View (RBV) (Penrose, 1959; Barney, 1991 and 1996), which places greater emphasis on the value (rather than on the costs) of the activities that are offshored (Madhok, 1997 and 2002; Meyer, Wright and Pruthi, 2009; Mudambi and Tallman, 2010; Castañer, Mulotte, Garrette and Dussauge, 2014). According to the RBV perspective, firms expand abroad through captive entry modes for two reasons. First, a captive solution enables a more efficient exploitation of the competitive advantage by leveraging internal routines, including the transfer of knowledge between the parent and the subsidiary. Second, the wholly-owned solution provides the firm with greater strategic and operational control over foreign operations, thus reducing the risk of value erosion by third parties, especially when the competitive advantage is based on tacit and embedded components (Madhok, 1997 and 2002; Brouthers, Brouthers and Werner, 2008). The Knowledge Based View (KBV), which is an extension of the RBV identifies knowledge as the most strategic resource, and suggests that the key challenge for an internationalizing firm is to facilitate the transfer of competences and manage the information flow within the organization. Indeed, MNEs must possess superior capacity for planning, contextual communication of information, and protection of knowledge compared to markets, and this makes the captive entry mode a better solution (Alchian \& Demsetz, 1972; Arrow, 1974; Kogut and Zander, 1992; Monteverde, 1995). Within the KBV context, Nickerson \& Zenger (2004) state that activities that can be fully decomposable can be coordinated by the market, while interdependent activities are better managed within a single organization for knowledge process purposes.

In our paper, we bridge these alternative and complementary theoretical perspectives by introducing the concept of modularity in the entry mode choice. Although these theories build on rather different arguments, they do agree that interdependent and synergetic activities are managed more efficiently when consolidated within a single firm than when distributed across companies (Baldwin, 2008; Baldwin \& Clark 2000: Ch. 14; Langlois, 2002; Teece, 1996). Therefore, both theoretical perspectives agree that offshoring firms are expected to mirror the entry mode choice in 
the technical architecture of the business function, by selecting a hierarchical entry mode if the activity is strongly interdependent with others, and a market-based entry mode if the activity is modular, i.e., if it is independent and can be outsourced without risking losing synergies among other activities.

There are several reasons why a modular technical architecture is expected to lead to the mirroring of a market-based entry mode choice. Manufacturing industries can take advantage of the modular technical architecture of a product by exploiting common and standardized platforms that allow sharing components, thus increasing the opportunity of using market transactions and decreasing the costs to acquire inputs (MacDermott, Mudambi \& Parente, 2013). Business functions can also benefit from a modular technical architecture. Indeed, the modularization of business functions offers the opportunity to reduce complexity, to learn more quickly and to adapt more rapidly to market and technology changes, thus reducing the costs, and increasing the effectiveness, of transferring knowledge across boundaries (Kotabe, Parente \& Murray, 2007). Disintegrating the value chain of business functions into smaller, independent modules also reduces the exposure and leakage of proprietary knowledge to third parties (Gooris \& Peeters, 2016), thus enabling value chain orchestrators to face lower transaction costs during the negotiating and monitoring phases, which in turn translates into a lower need for internalization.

Furthermore, a modular technical architecture improves the strategic and operational flexibility of business functions, thus leading to higher efficiency in resource allocation, since it enables firms to exploit economies of scale and shift some modules to new product development (Baldwin \& Clark, 2000). Additionally, modularization increases firms' opportunities to interact with different external suppliers for specific support functions and processes involving design, engineering, research and development, analytical processes, data processing, etc. These opportunities enable the client to exchange knowledge and expertise with each supplier, which in turns increases the scope of firm's capabilities and innovation activity (Baldwin \& Clark, 1997 and 2000; Langlois \& Robertson, 1992; Parente, Baack \& Hahn, 2011). 
In sum, modular technical architecture allows firms to: (i) reduce transaction costs, (ii) increase the efficiency of the internal resource allocation; (iii) increase the effectiveness of competence and knowledge transfer and sourcing across external companies; (iv) reduce knowledge leakages risks. This, in turns, implies that a company will be more likely to select an outsourcing solution when the technical architecture of the business functions is modular and therefore the organizational architecture in terms of entry mode choice will be less hierarchical, as suggested by the mirroring hypothesis. Conversely, a non-modular technical architecture is made of interdependent activities and faces high risk of loss of synergies in case of separation; therefore it will be more efficient to mirror a more hierarchical entry mode choice.

Hence, we expect the following hypothesis to hold:

Hypothesis 1: A modular (non- modular) technical architecture will mirror an outsourcing (captive) solution when offshoring a business function

\section{The level of disintegration and the mirroring hypothesis}

As discussed in the previous section, modularity enables the reduction of knowledge leakages risks and transaction costs, and this will imply the mirroring of an outsourcing solution in the entry mode choice. However, the disintegration of the value chain requires also strong efforts to reintegrate the modules into the system (Baldwin \& Clark, 1997; Cacciatori \& Jacobides, 2005; Kotabe, Parente \& Murray, 2007; Langlois \& Robertson, 1992; Parente, Baack \& Hahn, 2011).

Here we argue that the intensity of the reintegration challenges can vary with the level of disintegration implemented by the company, i.e. the number of distinct micro-activities in which a given macro-activity can be meaningfully divided. Indeed, modularity has been defined as "an attribute of a complex system that advocated designing structures based on minimizing interdependence between modules and maximizing interdependences within them that can be mixed and matched in order to obtain new configurations without loss of system's functionality or 
performance" (Campagnolo and Camuffo, 2010: 259). Hence it becomes crucial to identify the "between" and "within" contingencies in order to understand the extent to which modularity can effectively decrease transaction costs and knowledge leakages risks consistently with the mirroring hypothesis.

To this end, we rely on Gooris and Peeters (2016) to distinguish between two different levels of disintegration. On the one hand, firms can separate the value chain across different business functions (such as R\&D, marketing and sales, call centers etc.). On the other hand, they can further stretch the level of disintegration of the value chain by adopting a "functional fine-slicing", i.e. the separation of each business function into smaller, single tasks (such as the billing activity within the marketing and sales division).

We propose that reintegration costs are potentially lower when the disintegration of the value chain with - rather than without - functional fine-slicing. Indeed, when fine-slicing and offshoring, companies need to coordinate and re-connect tasks that belong to the same function and that share a common platform in terms of routines, interfaces, business practices, etc. The opposite is true in case of offshoring without functional fine slicing, since each function relies on specializations and managerial practices that are different one from the others, thus raising higher reintegration costs. This challenge is exacerbated when one or more functions are outsourced, i.e. when more than one firm is involved (Lew et al., 2016), since in this case the platforms need to be reconnected not only across functions but also across firms.

Accordingly, we argue that the extent to which the firm will comply with the mirroring hypothesis is contingent on the level of disintegration, and that firms implementing disintegration without functional fine-slicing will be much more concerned about the potential reintegration costs. In this case, modular technical architecture might not be sufficient to ensure an effective cost and risks reduction strategy when offshoring. Therefore, a firm will be more likely to select a hierarchical entry mode in order to internalize such costs and risks, even when the technical architecture of the business function is modular, thus "breaking" the mirroring hypothesis (Colfer \& 
Baldwin, 2016). Conversely, firms that implement functional fine-slicing when offshoring can align more easily entry mode choice and technical architecture of their activity, thus complying with the mirroring hypothesis. Therefore, we expect the following hypothesis to hold:

Hypothesis 2: The probability that modular (non-modular) technical architecture will mirror an outsourcing (captive) solution is higher in case of offshoring with functional fine-slicing than without functional fine-slicing

\section{Company experience and the mirroring hypothesis}

We propose that the extent to which firms comply with the mirroring hypothesis is also contingent on the firms' familiarity with offshoring. Firms with no offshoring experience are more likely to be unaware of the advantages arising from mirroring technical and organizational architectures. Additionally, firms that are new to offshoring are also likely to be less capable to face not only the reintegration efforts but also the so-called "hidden costs" of offshoring (Cacciatori \& Jacobides, 2005; Larsen, Manning \& Pedersen, 2013). The "hidden costs" are typically due either to external contingencies or factors that are internal to the company undertaking an offshoring initiative (Cacciatori \& Jacobides, 2005; Larsen, Manning \& Pedersen, 2013). External contingencies arise, for example, when firms discover that the local labor and resource costs inflate beyond initial estimations or that the local market is growing less than expected (Larsen, 2016). Internal factors may arise from managerial mistakes in planning and implementing the offshoring initiatives or from underestimating the efforts required to manage it and to reintegrate the module into the system. The main consequences of these unexpected challenges are: more intensive monitoring, higher coordination efforts, increased knowledge misappropriation, risks of undermining core competencies, performance shortcomings and, eventually, the reshoring or backshoring of the foreign initiative (Albertoni et al., 2017; Dibbern, Winkler \& Heinz, 2008; Gooris \& Peeters, 2016; Larsen, Manning \& Pedersen, 2013; Reitzig \& Wagner, 2010). 
Therefore, inexperienced firms will be less likely to comply with the mirroring hypothesis, due to their lower awareness of the benefits arising from this strategy and due to their limited capability to plan, set up and manage the foreign venture, and underestimating the hidden and reintegration costs of offshoring. Conversely, experienced firms are expected to have learned from previous offshoring initiatives and be better positioned to consider the benefits of mirroring technical and organizational architectures when making offshoring decisions. Experienced firms will also be able to estimate more accurately most of the reintegration and hidden costs associated to offshoring and, in particular, to outsourcing, thus facing lower post-implementation efforts (see Asmussen, Larsen \& Pedersen, 2016). Thus, they will be more confident to comply with the mirroring hypothesis than inexperienced firms. Hence, our third hypothesis is:

\section{Hypothesis 3: The probability that modular (non-modular) technical architecture will mirror an outsourcing (captive) solution when offshoring a business function is larger when firms have at least one previous offshoring experience.}

\section{Data and methodology}

The sample

We test our hypotheses on a sample of 486 offshoring initiatives worldwide from 1964 to 2009. Data are provided by the Offshoring Research Network (ORN) and derive from a survey project launched in 2004 by the Center for International Business Education and Research (CIBER) of Duke University in the United States, which has been collecting information at the level of the individual offshoring initiative ${ }^{\mathrm{i}}$. Table 1 shows the business functions involved in the offshoring initiatives. Information Technology is the function mostly subject to offshoring, accounting for 96 observations (19.80\% of the sample), followed by Software Development ( 84 observations, $17.35 \%$ of the sample), Call Center and Customer Contact (69 observations, $14.08 \%$ of the sample), Finance 
and Accounting (56 observations, $11.43 \%$ of the sample) and Engineering Services (44 observations, $8.98 \%$ of the total).

INSERT TABLE 1 ABOUT HERE

Table 2 displays the main home countries of the 486 offshoring initiatives. The United States account for 310 initiatives (63.67\%), followed by The Netherlands with 87 initiatives (17.96\%) and Switzerland with 25 initiatives $(5.10 \%)$.

INSERT TABLE 2 ABOUT HERE

Table 3 shows the host countries of the offshoring initiatives. The most popular destination is India, which hosts 219 offshoring initiatives (45.10\%), followed by China with 47 initiatives (9.8\%) and the Philippines with 39 initiatives (7.96\%).

\section{INSERT TABLE 3 ABOUT HERE}

\section{The variables}

Dependent variable. Our dependent variable, Entry mode hierarchy, derives from the following question in the ORN survey: "What is the service delivery model currently used for this offshoring implementation?" The possible answers were: “Outsourced to an international third party provider offshore"; "Outsourced to a local third party provider at the offshore location"; "Partnering/teaming arrangement e.g., joint ventures, strategic alliances, build-operate-transfer"; "Captive (i.e. fully owned subsidiary offshore undertakes the activity)". We categorized the answers as Entry mode hierarchy $=0$ if companies answered "Outsourced to an international third party provider offshore" or "to a local third party provider at the offshore location"; Entry mode hierarchy=1 if the companies answered "Partnering/teaming arrangement e.g., joint ventures, strategic alliances, build- 
operate-transfer"; and Entry mode hierarchy=2 if companies answered "Captive (fully owned subsidiary offshore undertakes the activity)". The categorization of the entry mode choice through a scale variable has been employed in the literature to account for the intensity of the commitment by firms engaging in foreign expansion (see, for instance, Basile, Giunta \& Nugent, 2003). In our sample, 195 observations (corresponding to $40.1 \%$ ) have been classified as captive, 16 observations (corresponding to $3.3 \%$ ) as cooperative agreements, and 275 observations (corresponding to 56.6\%) as outsourcing.

Explanatory variables. The main explanatory variable is business functions modularity, which reflects the technical modularity of business functions. This is a scale variable whose lower values indicate interdependence among the modules, while high values indicate that modules are independent. The proxy variable is computed from the answers to the question in the ORN survey: "What is the importance of each of the following risks in considering offshoring this function?" in relation to the risk of "Loss of synergy across firm activities". Given the original score (ranging from 1 to 5), we reverse-coded the values in order to obtain a proxy that associates a high score (i.e. -1) to low risk of losing synergy across firm activities, which happens in the case of low interdependence and high technical modularity, and a low score (i.e. -5) to high risk of losing synergy across firm activities, which occurs in the case of high interdependence and low technical modularity. By referring to the synergies among business activities (and the risk of losing them) our proxy captures the extent to which the focal business function is characterized and affected by technical modularity. Following our first hypothesis, we expect a negative relation between the dependent variable and the proxy of business function modularity, so that high business function modularity will mirror a lower probability to select an organizational architecture based on a hierarchical entry mode. The mean value of the business functions modularity variable is slightly higher when considering the observations with outsourcing entry mode than with captive entry 
mode ( -2.50 vs. -2.81 , respectively), and the t-test confirms that the two means are statistically significantly different $(\mathrm{p}<0.01)$, thus providing some first evidence towards our Hypothesis 1.

A second explanatory variable is functional fine-slicing, which was derived from the question in the ORN survey: "Does/did this implementation involve discrete tasks or entire processes?" This is operationalized as a binary variable taking a value of 1 when the company answers that the implementation involves one or more single tasks within a business function, and 0 when the company answers that the implementation involves the entire process, i.e. the whole business function. In our sample, 303 observations refer to offshoring initiatives that have been performed for discrete tasks (i.e. dummy variable $=1$ ) and the remaining 183 are about offshoring initiatives that involved the entire business process (i.e. dummy variable=0). We expect that functional fineslicing is negatively associated to the dependent variable, i.e. that less hierarchical entry modes are more likely in case of fine-slicing of business functions, as it reduces transaction costs and misappropriation risks (Gooris \& Peeters, 2016). In our dataset outsourcing is more frequent than captive when firms offshore a single task (63.4\% vs. $33.3 \%$ vs., respectively), while the opposite is true when they offshore the entire process ( $45.4 \%$ vs. $51.4 \%$, respectively). Following our second hypothesis, we expect that the mirroring hypothesis holds when within-function modularity takes value of 1.

A third explanatory variable is Offshoring Experience, a binary variable taking value of 1 when the company undertaking offshoring has at least one previous offshoring activity and 0 if the company has no offshoring experience. This variable is computed from the ORN database. In our sample, 219 observations display no previous offshoring experience (binary variable=0), while 267 observations display offshoring experience (binary variable=1). Outsourcing is selected more frequently by inexperienced than by experienced firms ( $63.9 \%$ vs. $50.6 \%$, respectively), while the opposite is true for captive entry mode (33.3\% vs. $45.7 \%$, respectively). 
Control variables. We include control variables that may affect the entry mode choice at firmlevel, country-level, initiative-level, industry-level and function-level, in order to better account for the complexity of the offshoring phenomenon, which is investigated at different levels of analysis (Hätönen \& Eriksson, 2009; Oshri, Kotlarsky \& Willcocks, 2015).

About firm-level variables, we use Firm Size to control for the effect of firm dimension on entry mode choice, as large firms, which are normally endowed of more resources compared to smaller firms, are better positioned to select a captive entry mode, which requires higher resource commitment and is preferred for larger scale operations. The proxy is the natural logarithm of number of employees of the offshoring firm (data provided by the ORN survey).

About country-level variables, following Brouthers (2002) and Elia, Caniato, Luzzini \& Piscitello (2014), we also control for the market and institutional context of the host country, by employing four variables arising from a factor analysis that has been performed on different items provided by the World Competitiveness Yearbook (WCY) and the Worldwide Governance Indicators (WGI) (see table 4 for details). Using data from multiple sources reduces the sample bias (e.g. common method bias) (Podsakoff, MacKenzie, Lee, \& Podsakoff, 2003) $)^{\text {ii }}$. The four variables are Host Political Stability, which accounts for the quality of the political infrastructures of the host country; Host Market Attractiveness, which reflects the potential market growth of host countries; Host Human Resources, which accounts for the amount of skilled labor available in the host country; Host Low Labor Cost ${ }^{i i i}$, which accounts for low cost of labor in the host countries. We expect that the probability to adopt a not hierarchical, market-oriented entry mode is larger when the availability of low labor cost is high, since in this case companies will take advantage of local service providers to outsource their activity and save on costs. Outsourcing will be more likely also when political stability is low, since a less hierarchical entry mode will limit the client companies' risk in countries with weak and uncertain institutions, and enables them to disinvest quickly if needed. At the same time, we expect that the probability to adopt a more hierarchical entry mode is higher in case of high market attractiveness and in case of availability of skilled labor, since firms 
will be better able to appropriate the rents arising from higher sales and from valuable resources if they have full control over their foreign activities. Therefore, we expect a negative correlation between the dependent variable and Low Labor Cost and a positive correlation with the other three host countries variables.

INSERT TABLE 4 ABOUT HERE

Since most of offshoring initiatives come from the United States, we also introduce the dummy variable Home USA to control whether US companies may drive the results on entry mode choice.

About the initiative-level variables, we include Cultural Distance, which is computed by applying the Kogut \& Singh (1988) index to the items provided by Hofstede (2001). Since cultural distance implies larger uncertainty and higher transaction costs, this variable is likely to increase the probability of adopting a captive entry mode, as suggested by Internalization theory and TCE. However, the company might also face the uncertainty arising from cultural distance through a risk reduction strategy, by adopting a lower control in their governance mode (Brouthers, 2002; Elia, Caniato, Luzzini and Piscitello, 2014). Hence, the impact of cultural distance is not predictable $a$ priori. We also control for the age of the initiative by creating a variable named Offshoring Age computed as the difference between the year 2011 (the most recent year when the survey has been released) and the year of the offshoring initiative. Finally, to account for the offshoring motivations that might affect the entry mode choice, we employ three variables reflecting the internationalization drivers identified by Dunning (1993), i.e. market-seeking investments, efficiency-seeking investments and strategic asset-seeking investments ${ }^{\mathrm{iv}}$. We control for these different types of investments by employing three variables based on a Likert scale scoring from 1 to 5 provided by the ORN survey. The variables derive from the answers to the question: "What is the importance of each of the following drivers in considering offshoring this function?", being three possible answers “Access to new markets for products and services” (market-seeking), 
"Enhancing efficiency through business process redesign" (efficiency-seeking) and "Access to qualified personnel offshore" (strategic asset seeking, i.e. human resources).

With regard to the industry-level variable, we control for High Tech and Knowledge Intensive Industries, a binary variable taking value 1 if the industry of the offshoring company belongs to the categories "Knowledge Intensive Service Industries”, "Medium-High Tech Manufacturing Industries" and "High Tech Manufacturing Industries" according to the classification provided by Eurostat-OECD (2007). The variable takes value of 0 if the industry of the offshoring company belongs to the categories "Less Knowledge Intensive Service Industries", "Medium-Low-Tech Manufacturing Industries", "Low-Tech Manufacturing Industries" according to the abovementioned classification ${ }^{v}$.

Finally, about the function-level variables, we control for the propensity that some business activities may present towards a certain entry mode, through 9 dummy variables accounting for the different business functions displayed in Table 1 by using Software Development as benchmark. We expect that those business functions that are strategically crucial for the competitive advantage of the firm (such as R\&D) are more likely to be subject to captive entry mode choice, as this solution should ensure a more effective transfer of the competitive advantage between organizational units located in different geographical area, as well as reducing transaction costs associated to high asset specificity and knowledge leakages risks.

Table 5 provides a summary of the variables employed in our analysis together with the proxies and their sources.

INSERT TABLE 5 ABOUT HERE

\section{Models and methodology}

To test Hypothesis 1, we estimate the following equation model: 
Entry mode hierarchy ${ }_{i}=\alpha_{i}+\boldsymbol{\beta}_{1}$ business functions modularity $_{i}+\boldsymbol{\beta}_{2}$ functional fine- $^{\text {fun }}$ slicing $_{i}+\boldsymbol{\beta}_{3}$ offshoring experience $_{i}+\boldsymbol{\beta}_{4}$ controls $_{i}+\varepsilon_{i}$

where $i$ identifies the offshoring initiative and $\varepsilon_{i}$ the error term.

To test Hypotheses 2 and 3, which assess respectively the effect of within-function modularity and the effect of offshoring experience on the mirroring hypothesis, following Greene (2010) we split the sample and compared the coefficients across subsamples, rather than using the interaction coefficients (see Gooris \& Peeters, 2016 for a similar recent application). According to Greene (2010), the estimation technique based on interaction in non-linear models (as also suggested by Norton et al., 2004) is "generally uninformative and sometimes contradictory and misleading”. Therefore, Greene (2010) recommends to address interaction effects through model design (which, as in Gooris \& Peeters, 2016, comes from splitting the sample), rather than by estimating interaction coefficients at the analysis stage.

Therefore, to test Hypothesis 2 we created two subsamples, the first one accounting for offshoring initiatives with functional fine-slicing (i.e. functional fine-slicing=1), the second one accounting for offshoring initiatives without functional fine-slicing (i.e. functional fine-slicing=0). We estimate the following equation model on each subsample:

Entry mode hierarchy ${ }_{i}=\alpha_{i}+\beta_{1}$ business functions modularity $_{i}+\beta_{2}$ offshoring experience $_{i}+\beta_{4}$ controls $_{i}+\varepsilon_{i}$

We create two subsamples also to test Hypothesis 3, by identifying offshoring initiatives in experienced companies (when the variable Offshoring Experience is equal to 1) and offshoring initiatives in companies with no prior experience (when the variable Offshoring Experience is equal to 0$)$. We estimate the following equation model on each subsample:

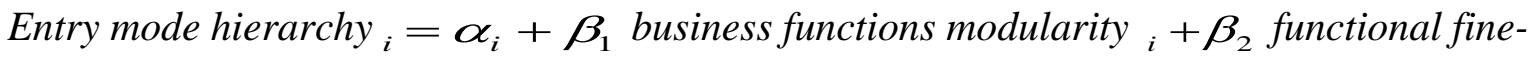
slicing $_{i}+\beta_{3}$ controls $_{i}+\varepsilon_{i}$ 
Given the nature of the dependent variable, which quantifies hierarchical intensity into three values - 0 (corresponding to outsourcing), 1 (corresponding to intermediate entry modes, i.e., alliances and joint ventures), and 2 (fully owned, captive operations), we employed a robust Ordered Probit model (see Basile, Giunta \& Nugent, 2003). Table 6 reports the descriptive statistics and the correlation matrix of the explicative variables included in the analysis.

\section{INSERT TABLE 6 ABOUT HERE}

\section{Results}

Table 7 reports the results of the econometric analysis. Column (1) shows the results of the robust Ordered Probit applied to the full model, corresponding to Equation 1, while Columns 2a and $2 \mathrm{~b}$ shows the results of Equations (2) testing Hypothesis 2 and Columns $3 \mathrm{a}$ and $3 \mathrm{~b}$ the results associated to Equation (3) and testing Hypothesis 3. The full model in Column 1 shows that business functions modularity displays a negative and significant effect on the dependent variable (0.117, $\mathrm{p}<0.05$ ), thus supporting Hypothesis 1 , according to which business functions with modular technical architecture are more likely to mirror more modular organizational architectures (i.e., outsourcing) when selecting the entry mode. Marginal effects (available upon request) confirm that outsourcing entry modes are more likely when business functions are modular. The opposite is true when considering captive initiatives. Conversely, hybrid entry modes do not seem to be significantly affected by the business function modularity.

As expected, functional fine-slicing displays a negative sign $(-0.569, \mathrm{p}<0.01)$, thus confirming that fine-slicing reduces the need for hierarchical entry modes. Conversely, Offshoring experience displays a positive and significant effect $(0.343, \mathrm{p}<0.01)$, suggesting that experienced firms tend to prefer captive entry modes to outsourcing. Outsourcing is probably used by inexperienced firms as a first step to invest in a foreign country, consistently with the stage strategy suggested by the Uppsala model (Johanson \& Vahlne, 1977). This may also be due to the fact that more inexperienced firms are offshoring in more recent years, when more service providers have started 
operations in low cost countries, which makes it easier to select outsourcing than in the past (e.g., Manning, Massini, Peeters \& Lewin, 2012). Regarding the control variables, political stability, as expected, increases the probability of adopting a captive governance mode $(\mathrm{p}<0.10)$. Cultural distance displays a strong positive and significant $(\mathrm{p}<0.05)$ effect, suggesting that firms are more likely to adopt captive solutions to internalize transaction costs arising from uncertainty when cultural differences are large. Offshoring age presents a positive and significant coefficient $(\mathrm{p}<0.01)$ indicating that the probability to select a captive entry mode is higher for long standing offshoring initiatives, that is, older offshoring decisions prefer a captive mode, whereas more recent, shorter offshoring initiatives tend to make more use of external providers. Again, this may be due to the increased availability of service providers in the more recent years. Firms are more likely to adopt a captive solution also in case of market-seeking investments $(\mathrm{p}<0.01)$, as this type of entry mode enables internalizing the profits arising from sales in the host country. Finally, some of the most strategic business functions, which tend to be characterized by higher asset-specificity, show higher probability to adopt a captive governance mode, e.g., Finance and Accounting $(\mathrm{p}<0.05)$, Human Resources and R\&D ( $<<0.10)$, which is consistent with these functions often being responsible for the main competitive advantage of the firm, and entailing higher transaction costs and risks of knowledge leakages.

Columns $2 \mathrm{a}$ and $2 \mathrm{~b}$ report the estimation of Equation 2 on the two subsamples of companies with and without functional fine-slicing, respectively. Results show that business functions modularity has a significant and negative effect on the dependent variable $(-0.182, \mathrm{p}<0.05)$ in the subsample with functional fine-slicing (column 2a), but not in the subsample without functional fine-slicing, thus confirming Hypothesis 2.

Finally, Columns 3a and 3breport the results of Model 3 estimated in the two subsamples of experienced and inexperienced firms, respectively. The variable business functions modularity is significant only for experienced firms $(-0.179, \mathrm{p}<0.05)$, thus supporting hypothesis 3 . 


\section{INSERT TABLE 7 ABOUT HERE}

\section{Robustness checks and additional analyses}

We ran additional models to test the robustness of our choices in terms of operationalization of variables and samples. Since the operationalization of the dependent variable, entry mode choice, includes an intermediate category which pools both equity (i.e. joint-ventures) and non-equity (i.e. strategic alliances) agreements, with the former being closer to the captive entry mode and the latter to outsourcing, the results of the Ordered Probit model might be biased by the presence of this hybrid intermediate group. Although this category only represents a small percentage of the total observations, we estimated three alternative Probit models for robustness: the first model includes only captive and outsourcing entry modes (corresponding to 470 observations); the second model pools the hybrid entry modes with the captive observations (as if they were all joint ventures), and the third model includes the hybrid entry modes in the outsourcing observations (as if they were all alliances). Results, which are available upon request, confirm that business functions modularity decreases the probability of adopting a captive entry mode in all the three Probit models. In addition, Hypotheses 2 and 3 are fully confirmed.

Following the most recent literature, which suggests to investigate the effects of the cultural distance and institutional context on modularity (see, for instance, Lew et al., 2016), we carry out additional analyses in order to understand whether the mirroring hypothesis is subject to further contingencies. We created two additional pairs of subsamples. The first one distinguishes between offshoring initiatives located in high vs. low culturally distant host countries, by employing the mean of the variable Cultural Distance (i.e. 2.171) as threshold. The second one separates offshoring initiatives undertaken in countries with high vs. low political stability, by using the mean of the variable Host Political Stability (i.e. 23.786) as threshold.

The results of the Ordered Probit model, which are displayed in Table 8, suggests that the mirroring hypothesis is contingent on both cultural distance and political stability. The variable 
Business functions modularity turns out to be negatively and significantly correlated with the dependent variable only when the cultural distance between the home and host country is low $(\mathrm{p}<0.05$ in column 2) and when the political stability of the host country is high ( $p<0.05$ in column 3$)$. Conversely, firms selecting the entry mode choice when offshoring in unstable and culturally distant countries seem to be less concerned about aligning the technical and organizational architectures.

\section{Discussion and conclusions}

Our paper develops theoretical arguments and provides empirical results adding nuances to the mirroring hypothesis in the selection of the entry mode choice when offshoring business functions. Specifically, we show that modular business functions mirror a less hierarchical entry mode, because modular technical architectures allow simultaneously decreasing the need for internalization and increasing the effectiveness of the knowledge sourcing strategy that often underlies business function offshoring. Conversely, business functions which are not modular tend to mirror a more hierarchical entry mode choice, in order to ensure lower transaction costs and higher protection of proprietary knowledge. We also show that the mirroring hypothesis is contingent upon the type of disintegration adopted in the offshoring venture and upon the firms' experience. Finally, our post-hoc analysis shows that the mirroring hypothesis is contingent also on the cultural distance between the home and host country and on the political stability of the host country, implying that firms are more likely to align technical and organizational architecture in cultural close and political stable contexts.

\section{Contributions to the literature}

Our paper provides a contribution to two streams of literature, i.e. the mirroring hypothesis in the organizational literature and the entry mode choice in the international business literature, by bridging their (complementary) theoretical perspectives. Our analysis shows that the challenges arising from a low level of disintegration of the value chain and from global sourcing inexperience 
hinder the extent to which companies are willing or capable to align technical and organizational architectures. Companies offshoring an entire business function will be more focused on implementing strategies that decrease the potential reintegration costs arising from betweenfunctions disintegration. With regard to offshoring experience, firms are likely to be unaware of the potential benefits of the mirroring hypothesis and to be less capable of planning and implementing an effective offshoring strategy due to its hidden costs. Finally, the higher transaction costs and knowledge leakages risks associated to cultural distant and unstable countries also seem to reduce the effectiveness and the attractiveness of mirroring.

As pertains the debate on entry mode choice in the international business literature we provide a contribution in several ways. First, we have combined different theoretical perspectives and explored the joint impact of TCE and RBV factors. Specifically, this paper highlights how the implications of these two different schools of thought can be combined under the umbrella of the mirroring hypothesis (Colfer \& Baldwin, 2016), by proposing an alternative explanation to why firms select make or buy (Hätönen and Eriksson, 2009; Pereira and Malik, 2015). Second, we explicitly introduce the role of modularity to the analysis of entry mode choice. Third, this paper shows how strong synergies among activities induces firms to select captive solutions, and how different levels of disintegration imply different challenges in terms of reintegration costs of the modules due to heterogeneous routines, interfaces, business practices etc.. The paper provides evidence that also the entry mode choice is subject to contingencies such as firm-level (i.e. experience) and country-level (i.e. cultural distance and political context of the host country) variables.

Finally, our paper provides a further element of novelty by applying the concept of modularity to the context of business functions. We believe that the implications of our paper can be extended beyond this specific context. Indeed, also manufacturing activities can be subject to strong transaction costs and knowledge leakages risks, even if they are more tangible and are not characterized by the simultaneous consumption and production as in the case of business functions, 
and therefore, all the implication arising from the modularity and the mirroring hypothesis are likely to hold in other sectors. Hence, we believe that our results have some degree of generalizability as regards the contingencies of the mirroring hypothesis and the role of modularity in the entry mode choice also for activities different from business functions.

\section{Managerial implications}

Our study offers managerial implications. First, we show that firms tend to mirror the technical and the organizational architectures, by aligning (not-) modular business functions with the selection of (more) less hierarchical entry modes, an aspect that managers should take into account to better manage the offshoring venture. Additionally, we suggest that firms should focus their efforts on increasing modularization, if possible, in order to take advantage of the associated benefits in terms of lower transaction costs and knowledge leakages risk. In other words, a offshoring strategy should be matched with (or even better, preceded by) a modularization strategy based on codified interfaces, which allows outsourcing to a higher extent and at lower costs and risks than what would otherwise be possible. This in turn should have strong performance effects.

Second, we alert firms about the contingent effect of the locus and level of disintegration, by suggesting greater attention be paid to the reintegration costs when offshoring an entire business function (rather than single tasks within a business function) before applying the mirroring strategy. We also alert inexperienced firms to the consequences of neglecting mirroring as a strategic dimension. We suggest that inexperienced firms should adopt strategies (e.g. implementing a due diligence activity or contacting consultancy companies) aimed at increasing their awareness and understanding of the relationship between business functions and firms' boundaries and their ability to anticipate and absorb hidden and reintegration costs of offshoring, in order to take advantage of the benefits arising from mirroring the technical and organizational architectures at the time of their first offshoring initiative. Finally, we warn companies from the overestimation of the benefits arising from the mirroring hypothesis in culturally distant and politically unstable host countries. 


\section{Future developments}

Our study is not exempt from limitations. Future research should try to develop more accurate measures of technical architecture of the business functions, e.g. by developing metrics based on an objective assessment of its dimensions. Additionally, they should better investigate to what extent modularity is an exogenous characteristics of the business function or a choice made by the firms, in order to provide more insights on whether, when and how it is possible to implement a modularization strategy before internationalizing. Future studies should also try to introduce more fine-grained measures of the level of disintegration, e.g., by employing a more nuanced scale variable, instead of a binary variable, also in relation to its extent within the organization. Further contingencies affecting mirroring hypothesis might also be explored, such as the specific effect of different types of industries and different categories of functions. Finally, future studies should try to investigate intermediate entry mode choices in greater depth, such as equity and non-equity collaborations, by disentangling how the mirroring hypothesis apply to the decision of whether (and to what extent) to collaborate with external firms (Narula \& Martínez-Noya, 2015). 
Tables

Table 1: Business functions involved in the offshoring initiatives.

\begin{tabular}{lcc}
\hline \multicolumn{1}{c}{ Business Function } & Freq. & \% \\
\hline Software Development & 84 & 17.35 \\
Call center and customer contact & 69 & 14.08 \\
Design & 17 & 3.47 \\
Engineering services & 44 & 8.98 \\
Finance and accounting & 56 & 11.43 \\
Human resources & 12 & 2.45 \\
Information technology & 96 & 19.80 \\
Knowledge services & 30 & 6.53 \\
Legal services & 3 & 0.61 \\
Marketing and sales & 27 & 5.51 \\
Procurement & 27 & 5.51 \\
Research and development & 13 & 2.65 \\
Other* & 8 & 1.63 \\
\hline Total & $\mathbf{4 8 6}$ & $\mathbf{1 0 0}$ \\
\hline
\end{tabular}

* A small number of respondents have not been able to find a match between the offshored function and the ones proposed in the questionnaire

Table 2: Home countries of the offshoring initiatives.

\begin{tabular}{lcc}
\hline \multicolumn{1}{c}{ Home countries } & Freq. & $\mathbf{\%}$ \\
\hline Australia & 7 & 1.43 \\
Austria & 1 & 0.20 \\
Denmark & 10 & 2.04 \\
France & 6 & 1.22 \\
India & 1 & 0.20 \\
Ireland & 1 & 0.20 \\
Japan & 1 & 0.20 \\
Luxembourg & 1 & 0.20 \\
Norway & 4 & 0.82 \\
Spain & 14 & 2.86 \\
Switzerland & 25 & 5.10 \\
The Netherlands & 87 & 17.96 \\
United Kingdom & 18 & 3.88 \\
United States & 310 & 63.67 \\
\hline Total & $\mathbf{4 8 6}$ & $\mathbf{1 0 0}$ \\
\hline
\end{tabular}


Table 3: Host countries of the offshoring initiatives.

\begin{tabular}{|c|c|c|}
\hline Host countries & Freq. & Percent \\
\hline India & 219 & 45.1 \\
\hline China & 47 & 9.80 \\
\hline Philippines & 39 & 7.96 \\
\hline Brazil & 12 & 2.45 \\
\hline Mexico & 12 & 2.45 \\
\hline Singapore & 11 & 2.45 \\
\hline Canada & 11 & 2.24 \\
\hline Czech Republic & 9 & 1.84 \\
\hline Argentina & 8 & 1.63 \\
\hline Costa Rica & 8 & 1.63 \\
\hline Malaysia & 8 & 1.63 \\
\hline Romania & 8 & 1.63 \\
\hline Russia & 8 & 1.63 \\
\hline Poland & 7 & 1.43 \\
\hline Germany & 6 & 1.22 \\
\hline Hungary & 6 & 1.22 \\
\hline United States & 6 & 1.22 \\
\hline Indonesia & 5 & 1.02 \\
\hline Sweden & 5 & 1.02 \\
\hline United Kingdom & 5 & 1.02 \\
\hline Italy & 4 & 0.82 \\
\hline South Africa & 4 & 0.82 \\
\hline France & 3 & 0.61 \\
\hline Norway & 3 & 0.61 \\
\hline Slovakia & 3 & 0.61 \\
\hline Australia & 2 & 0.41 \\
\hline Denmark & 2 & 0.41 \\
\hline El Salvador & 2 & 0.41 \\
\hline Finland & 2 & 0.41 \\
\hline Japan & 2 & 0.41 \\
\hline Luxembourg & 2 & 0.41 \\
\hline Pakistan & 2 & 0.41 \\
\hline Vietnam & 2 & 0.41 \\
\hline Other countries* & 13 & 2.6 \\
\hline Total & 486 & 100 \\
\hline
\end{tabular}

*Other countries include: Colombia, Ecuador, Estonia, Ireland, Jamaica, The Netherlands, Peru, Portugal, South Korea, Taiwan, Thailand, Turkey and Uruguay, each hosting only one initiative. 
Table 4: Factor analysis for the host country variables

\begin{tabular}{|c|c|c|c|c|c|c|}
\hline First order construct & Items & Source & Description & Scale & Loading & Alpha \\
\hline \multirow{5}{*}{ Market Attractiveness } & Gross Domestic Product & WCY & Gross Domestic Product & US\$ billions & 0.9864 & \multirow{5}{*}{0.7939} \\
\hline & Gross Fixed Capital Formation & WCY & Inward Foreign direct investments & US\$ billions & 0.9519 & \\
\hline & Direct Investment Inflows Inward & WCY & Direct Investment Inflows Inward & US\$ billions & 0.8724 & \\
\hline & Government Consumption Expenditure & WCY & Government Consumption Expenditure & US\$ billions & 0.9726 & \\
\hline & Household Consumption Expenditure & WCY & Household Consumption Expenditure & US\$ billions & 0.9698 & \\
\hline \multirow{5}{*}{ Political Stability } & $\begin{array}{l}\text { Political Stability and Absence of } \\
\text { Violence/Terrorism }\end{array}$ & WGI & $\begin{array}{l}\text { Perception of the likelihood that the government will be destabilized or } \\
\text { overthrown by unconstitutional or violent means, including politically- } \\
\text { motivated violence and terrorism. }\end{array}$ & $-2.5 / 2.5$ & 0.8783 & \multirow{5}{*}{0.9696} \\
\hline & Government Effectiveness & WGI & $\begin{array}{l}\text { Perception of the quality of public services, the quality of the civil } \\
\text { service and the degree of its independence from political pressures, the } \\
\text { quality of policy formulation and implementation, and the credibility of } \\
\text { the government's commitment to such policies. }\end{array}$ & $-2.5 / 2.5$ & 0.8556 & \\
\hline & Regulatory Quality & WGI & $\begin{array}{l}\text { Perception of the ability of the government to formulate and implement } \\
\text { sound policies and regulations that permit and promote private sector } \\
\text { development. }\end{array}$ & $-2.5 / 2.5$ & 0.9011 & \\
\hline & Rule of Law & WGI & $\begin{array}{l}\text { Perceptions of the extent to which agents have confidence in and abide } \\
\text { by the rules of society, and in particular the quality of contract } \\
\text { enforcement, property rights, the police, and the courts, as well as the } \\
\text { likelihood of crime and violence. }\end{array}$ & $-2.5 / 2.5$ & 0.8859 & \\
\hline & Control of Corruption & WGI & $\begin{array}{l}\text { Perceptions of the extent to which public power is exercised for private } \\
\text { gain, including both petty and grand forms of corruption, as well as } \\
\text { "capture" of the state by elites and private interests. }\end{array}$ & $-2.5 / 2.5$ & 0.8544 & \\
\hline \multirow{4}{*}{ Location Costs } & Remuneration Call Center Agent & WCY & $\begin{array}{l}\text { Gross annual income including supplements such as bonuses - Call } \\
\text { Center Agents }\end{array}$ & US\$ & 0.7480 & \multirow{4}{*}{0.7849} \\
\hline & Remuneration Manufacturing Worker & WCY & $\begin{array}{l}\text { Total hourly compensation for manufacturing workers (wages + } \\
\text { supplementary benefits) }\end{array}$ & US\$ & 0.7606 & \\
\hline & Remuneration Department Head & WCY & $\begin{array}{l}\text { Gross annual income including supplements such as bonuses - } \\
\text { Department Head }\end{array}$ & US\$ & 0.7254 & \\
\hline & Remuneration Personal Assistant & WCY & $\begin{array}{l}\text { Gross annual income including supplements such as bonuses - Personal } \\
\text { Assistant }\end{array}$ & US\$ & 0.7622 & \\
\hline \multirow{3}{*}{ High Value-Added Resources } & Information Technology Skills & WCY & $\begin{array}{l}\text { The extent to which the country can rely on information technology } \\
\text { skills }\end{array}$ & $0 / 10$ & 0.8036 & \multirow{3}{*}{0.9237} \\
\hline & Qualified Engineers & WCY & The extent to which qualified engineers are available in labor market & $0 / 10$ & 0.9310 & \\
\hline & Skilled Labor & WCY & The extent to which skilled labor is readily available in labor market & $0 / 10$ & 0.9000 & \\
\hline
\end{tabular}

Note: The factor analysis has been performed on 60 countries. The items have been included in the factor analysis as the average value of the period 2004-2011. Higher values reflect better outcomes for all items. WCY stands for World Competitiveness Yearbook (WCY), published by the International Institute for Management Development (IMD) of Lausanne (http://www.imd.org/wcc/), while WGI stands for Worldwide Governance Indicators (WGI), published by the World Bank (http://info.worldbank.org/governance/wgi/index.asp). 
Table 5: Summary of the variables, proxies and sources employed in our analysis.

\begin{tabular}{|c|c|c|c|}
\hline Variable & Type of variable & Proxy & Source \\
\hline Entry mode hierarchy & Dependent variable & $\begin{array}{l}\text { Variable ranging from } 0 \text { (Outsourcing) to } 2 \text { (Captive), being } 1 \text { cooperative agreements } \\
\text { (e.g. joint ventures and alliances) }\end{array}$ & $\begin{array}{l}\text { ORN Survey - answer to the question: "What is the service delivery model } \\
\text { currently used for this offshoring implementation?" }\end{array}$ \\
\hline $\begin{array}{l}\text { Business functions } \\
\text { modularity }\end{array}$ & Explicative variable & $\begin{array}{l}\text { Variable ranging from }-5 \text { to }-1 \text {, where the lower values }(-5) \text { reflect a high } \\
\text { interdependence among the modules, while high values }(-1) \text { mean that modules are } \\
\text { independent }\end{array}$ & $\begin{array}{l}\text { ORN Survey- Scores provided on a Likert scale to the risk "Loss of synergy } \\
\text { across firm activities" in answering the question: "What is the importance of each } \\
\text { of the following risks in considering offshoring this function?" (The proxy has } \\
\text { been computed by taking the negative values of the scores) }\end{array}$ \\
\hline Functional fine-slicing & Explicative variable & $\begin{array}{l}\text { Dummy variable taking value of } 1 \text { when the company offshores only a module of a } \\
\text { business service, and } 0 \text { when the company offshores the whole business service }\end{array}$ & $\begin{array}{l}\text { ORN Survey - answer to the question: "Does/did this implementation involve } \\
\text { discrete tasks or entire processes?" }\end{array}$ \\
\hline Offshoring Experience & Explicative variable & $\begin{array}{l}\text { Dummy variable taking value of } 1 \text { when the company undertaking offshoring has at } \\
\text { least one previous offshoring experience, and zero if the company is inexperienced }\end{array}$ & $\begin{array}{l}\text { ORN Survey - our elaboration obtained by identifying companies with previous } \\
\text { offshoring experiences in relation to the focal initiative. }\end{array}$ \\
\hline Firm Size & Firm-level control variable & Number of employees owned by the offshoring company & ORN survey \\
\hline Host Political Stability & Country-level control variable & Score from a factor analysis & Worldwide Governance Indicators (see table 4 for details) \\
\hline Host Market Attractiveness & Country-level control variable & Score from a factor analysis & World Competitiveness Yearbook (see table 4 for details) \\
\hline Host Human Resources & Country-level control variable & Score from a factor analysis & World Competitiveness Yearbook (see table 4 for details) \\
\hline Host Low Labor Cost & Country-level control variable & Score from a factor analysis & World Competitiveness Yearbook (see table 4 for details) \\
\hline Home USA & Country-level control variable & Dummy taking value of 1 if the offshoring firm is from The United States & ORN Survey \\
\hline Cultural Distance & Initiative-level control variable & Kogut and Singh (1988) index & Hofstede (2001) \\
\hline Market-seeking & Initiative -level control variable & Variable on a Likert scale (ranging from 1 to 5 ) & $\begin{array}{l}\text { ORN survey - score provided to the driver "Access to new markets for products } \\
\text { and services" as one of the possible answers to the question: "What is the } \\
\text { importance of each of the following drivers in considering offshoring this } \\
\text { function?" }\end{array}$ \\
\hline Efficiency-seeking & Initiative -level control variable & Variable on a Likert scale (ranging from 1 to 5) & $\begin{array}{l}\text { ORN survey - score provided to the driver "Enhancing efficiency through } \\
\text { business process redesign" as one of the possible answers to the question: "What } \\
\text { is the importance of each of the following drivers in considering offshoring this } \\
\text { function?" }\end{array}$ \\
\hline Human-resource seeking & Initiative -level control variable & Variable on a Likert scale (ranging from 1 to 5 ) & $\begin{array}{l}\text { ORN survey - score provided to the driver "Access to qualified personnel } \\
\text { offshore" as one of the possible answers to the question: "What is the importance } \\
\text { of each of the following drivers in considering offshoring this function?" }\end{array}$ \\
\hline $\begin{array}{l}\text { High Tech and Knowledge } \\
\text { Intensive Industries }\end{array}$ & Industry-level control variable & $\begin{array}{l}\text { Dummy variable taking value of } 1 \text { if the industry of the offshoring company belongs to } \\
\text { the categories "Knowledge Intensive Service Industries", "Medium-High Tech } \\
\text { Manufacturing Industries" or "High Tech Manufacturing Industries", and } 0 \text { if it belongs } \\
\text { to the categories "Less Knowledge Intensive Service Industries", "Medium-Low-Tech } \\
\text { Manufacturing Industries", and "Low-Tech Manufacturing Industries" }\end{array}$ & OECD (2007). \\
\hline Function Dummies & Function-level control variables & A dummy for each offshored function & ORN Survey \\
\hline
\end{tabular}


Table 6: Correlation matrix and descriptive statistics of the dependent and explicative variables

\begin{tabular}{|c|c|c|c|c|c|c|c|c|c|c|c|c|c|c|c|c|c|}
\hline \multicolumn{2}{|r|}{ Variable } & \multirow{2}{*}{$\frac{1)}{1.000}$} & \multirow[t]{2}{*}{ 2) } & \multirow[t]{2}{*}{ 3) } & \multirow[t]{2}{*}{ 4) } & \multirow[t]{2}{*}{ 5) } & \multirow[t]{2}{*}{$6)$} & \multirow[t]{2}{*}{ 7) } & \multirow[t]{2}{*}{ 8) } & \multirow[t]{2}{*}{ 9) } & \multirow[t]{2}{*}{ 10) } & \multirow[t]{2}{*}{ 11) } & \multirow[t]{2}{*}{ 12) } & \multirow[t]{2}{*}{ 13) } & \multirow[t]{2}{*}{ 14) } & \multirow[t]{2}{*}{ 15) } & \multirow[t]{2}{*}{ 16) } \\
\hline 1) & Entry mode hierarchy & & & & & & & & & & & & & & & & \\
\hline 2) & Business functions modularity & -0.129 & 1.000 & & & & & & & & & & & & & & \\
\hline 3) & Functional fine-slicing & -0.180 & -0.072 & 1.000 & & & & & & & & & & & & & \\
\hline 4) & Offshoring Experience & 0.132 & -0.052 & -0.038 & 1.000 & & & & & & & & & & & & \\
\hline 5) & Firm Size & -0.023 & -0.126 & -0.084 & 0.109 & 1.000 & & & & & & & & & & & \\
\hline 6) & Host Political Stability & 0.165 & -0.171 & -0.072 & 0.067 & -0.089 & 1.000 & & & & & & & & & & \\
\hline 7) & Host Market Attractiveness & -0.036 & 0.042 & 0.061 & -0.056 & -0.061 & -0.259 & 1.000 & & & & & & & & & \\
\hline 8) & Host Human Resources & -0.109 & -0.028 & -0.008 & -0.093 & 0.303 & 0.064 & 0.056 & 1.000 & & & & & & & & \\
\hline 9) & Host Low Labor Cost & 0.046 & -0.058 & 0.011 & 0.074 & 0.012 & 0.232 & 0.078 & -0.014 & 1.000 & & & & & & & \\
\hline 10) & Home USA & -0.119 & -0.025 & 0.060 & 0.109 & 0.162 & -0.034 & 0.132 & 0.230 & -0.073 & 1.000 & & & & & & \\
\hline 11) & Cultural Distance & 0.055 & 0.076 & -0.017 & 0.071 & 0.000 & -0.277 & -0.158 & -0.251 & -0.127 & -0.187 & 1.000 & & & & & \\
\hline 12) & Offshoring Age & 0.182 & -0.004 & -0.016 & -0.125 & -0.007 & 0.262 & -0.060 & -0.048 & 0.144 & -0.216 & -0.041 & 1.000 & & & & \\
\hline 13) & Market-seeking & 0.196 & -0.196 & 0.172 & 0.063 & -0.189 & 0.181 & 0.048 & -0.228 & 0.067 & -0.033 & -0.064 & 0.225 & 1.000 & & & \\
\hline 14) & Efficiency-seeking & 0.059 & -0.231 & 0.057 & 0.103 & 0.131 & 0.090 & -0.039 & 0.010 & 0.100 & -0.074 & -0.017 & 0.062 & 0.274 & 1.000 & & \\
\hline 15) & Human-resource seeking & -0.056 & -0.131 & 0.024 & -0.138 & -0.039 & -0.006 & 0.097 & -0.010 & 0.051 & 0.133 & -0.083 & -0.036 & 0.084 & 0.048 & 1.000 & \\
\hline 16) & $\begin{array}{l}\text { High Tech and Knowledge } \\
\text { Intensive Industries }\end{array}$ & -0.076 & -0.064 & -0.113 & -0.169 & -0.126 & -0.019 & 0.111 & 0.140 & -0.083 & 0.273 & -0.221 & -0.251 & -0.053 & -0.143 & 0.254 & 1.000 \\
\hline \multicolumn{2}{|c|}{ Observations } & 486 & 486 & 486 & 486 & 486 & 486 & 486 & 486 & 486 & 486 & 486 & 486 & 486 & 486 & 486 & 486 \\
\hline \multicolumn{2}{|c|}{ Mean } & 0.835 & -2.646 & 0.623 & 0.549 & 8.608 & 23.786 & 40.700 & 44.189 & 26.270 & 0.638 & 2.171 & 7.451 & 2.444 & 3.189 & 3.626 & 0.710 \\
\hline \multicolumn{2}{|c|}{ Std. Dev. } & 0.971 & 1.144 & 0.485 & 0.498 & 2.752 & 11.490 & 14.569 & 16.609 & 10.530 & 0.481 & 1.098 & 4.952 & 1.392 & 1.309 & 1.325 & 0.454 \\
\hline \multicolumn{2}{|l|}{ Min } & 0.000 & -5.000 & 0.000 & 0.000 & 0.693 & 4.000 & 4.000 & 3.000 & 2.000 & 0.000 & 0.020 & 2.000 & 1.000 & 1.000 & 1.000 & 0.000 \\
\hline \multicolumn{2}{|l|}{ Max } & 2.000 & -1.000 & 1.000 & 1.000 & 12.766 & 56.000 & 58.000 & 57.000 & 57.000 & 1.000 & 5.933 & 47.000 & 5.000 & 5.000 & 5.000 & 1.000 \\
\hline
\end{tabular}


Table 7: Results of the robust Ordered Probit models (dependent variable: Entry mode hierarchy).

\begin{tabular}{|c|c|c|c|c|c|}
\hline & Model 1 & Model 2a & Model 2b & Model 3a & Model 3b \\
\hline Variables & Full model & $\begin{array}{l}\text { With Functional } \\
\text { Fine-slicing }\end{array}$ & $\begin{array}{c}\text { Without } \\
\text { Functional } \\
\text { Fine-slicing }\end{array}$ & With experience & Without Experience \\
\hline Business functions modularity & $\begin{array}{c}-0.117 * * \\
(-2.06)\end{array}$ & $\begin{array}{c}-0.182 * * \\
(-2.22)\end{array}$ & $\begin{array}{l}-0.032 \\
(-0.33)\end{array}$ & $\begin{array}{c}-0.179 * * \\
(-2.25)\end{array}$ & $\begin{array}{l}-0.051 \\
(-0.56)\end{array}$ \\
\hline Functional fine-slicing & $\begin{array}{c}-0.569 * * * \\
(-4.31)\end{array}$ & - & - & $\begin{array}{c}-0.474 * * \\
(-2.57)\end{array}$ & $\begin{array}{c}-0.774 * * * \\
(-3.76)\end{array}$ \\
\hline Offshoring Experience & $\begin{array}{c}0.343 * * * \\
(2.59)\end{array}$ & $\begin{array}{l}0.408^{* *} \\
(2.21)\end{array}$ & $\begin{array}{c}0.435 * * \\
(1.96)\end{array}$ & - & - \\
\hline Firm Size & $\begin{array}{l}-0.004 \\
(-0.14)\end{array}$ & $\begin{array}{l}0.020 \\
(0.56)\end{array}$ & $\begin{array}{l}-0.044 \\
(-0.97)\end{array}$ & $\begin{array}{l}-0.013 \\
(-0.32)\end{array}$ & $\begin{array}{l}0.007 \\
(0.19)\end{array}$ \\
\hline Host Political Stability & $\begin{array}{l}0.011 * \\
(1.86)\end{array}$ & $\begin{array}{l}0.011 \\
(1.33)\end{array}$ & $\begin{array}{l}0.013 \\
(1.23)\end{array}$ & $\begin{array}{l}0.008 \\
(1.02)\end{array}$ & $\begin{array}{l}0.008 \\
(0.69)\end{array}$ \\
\hline Host Market Attractiveness & $\begin{array}{l}0.003 \\
(0.60)\end{array}$ & $\begin{array}{l}0.001 \\
(0.15)\end{array}$ & $\begin{array}{l}0.008 \\
(1.15)\end{array}$ & $\begin{array}{l}-0.002 \\
(-0.35)\end{array}$ & $\begin{array}{l}0.010 \\
(1.25)\end{array}$ \\
\hline Host Human Resources & $\begin{array}{l}-0.002 \\
(-0.52)\end{array}$ & $\begin{array}{l}0.001 \\
(0.18)\end{array}$ & $\begin{array}{l}-0.005 \\
(-0.68)\end{array}$ & $\begin{array}{l}-0.001 \\
(-0.12)\end{array}$ & $\begin{array}{l}-0.002 \\
(-0.30)\end{array}$ \\
\hline Host Low Labor Cost & $\begin{array}{l}-0.001 \\
(-0.18)\end{array}$ & $\begin{array}{l}0.005 \\
(0.70)\end{array}$ & $\begin{array}{l}-0.015 \\
(-1.35)\end{array}$ & $\begin{array}{l}-0.000 \\
(-0.04)\end{array}$ & $\begin{array}{l}-0.002 \\
(-0.20)\end{array}$ \\
\hline Home USA & $\begin{array}{l}-0.200 \\
(-1.36)\end{array}$ & $\begin{array}{l}-0.124 \\
(-0.58)\end{array}$ & $\begin{array}{l}-0.395^{*} \\
(-1.66)\end{array}$ & $\begin{array}{l}-0.251 \\
(-1.13)\end{array}$ & $\begin{array}{l}-0.172 \\
(-0.75)\end{array}$ \\
\hline Cultural Distance & $\begin{array}{c}0.120 * * \\
(2.08)\end{array}$ & $\begin{array}{l}0.192 * * \\
(2.31)\end{array}$ & $\begin{array}{l}0.019 \\
(0.21)\end{array}$ & $\begin{array}{c}0.173 * * \\
(2.40)\end{array}$ & $\begin{array}{l}0.040 \\
(0.36)\end{array}$ \\
\hline Offshoring Age & $\begin{array}{c}0.041 * * * \\
(2.70)\end{array}$ & $\begin{array}{l}0.014 \\
(0.81)\end{array}$ & $\begin{array}{c}0.088^{* * *} \\
(2.87)\end{array}$ & $\begin{array}{l}0.052 \\
(1.53)\end{array}$ & $\begin{array}{l}0.029^{*} \\
(1.84)\end{array}$ \\
\hline Market-seeking & $\begin{array}{c}0.172 * * * \\
(3.31)\end{array}$ & $\begin{array}{c}0.222 * * * \\
(3.34)\end{array}$ & $\begin{array}{l}0.187 \\
(1.64)\end{array}$ & $\begin{array}{c}0.152^{* *} \\
(2.04)\end{array}$ & $\begin{array}{c}0.246 * * * \\
(3.09)\end{array}$ \\
\hline Efficiency-seeking & $\begin{array}{l}-0.053 \\
(-1.00)\end{array}$ & $\begin{array}{l}-0.077 \\
(-0.98)\end{array}$ & $\begin{array}{l}-0.042 \\
(-0.51)\end{array}$ & $\begin{array}{l}-0.030 \\
(-0.39)\end{array}$ & $\begin{array}{l}-0.062 \\
(-0.72)\end{array}$ \\
\hline Human-resource seeking & $\begin{array}{l}-0.021 \\
(-0.41)\end{array}$ & $\begin{array}{l}-0.123^{*} \\
(-1.72)\end{array}$ & $\begin{array}{l}0.098 \\
(1.01)\end{array}$ & $\begin{array}{l}-0.067 \\
(-0.91)\end{array}$ & $\begin{array}{l}-0.061 \\
(-0.72)\end{array}$ \\
\hline $\begin{array}{l}\text { High Tech and Knowledge Intensive } \\
\text { Industries }\end{array}$ & $\begin{array}{l}0.001 \\
(0.00)\end{array}$ & $\begin{array}{l}-0.077 \\
(-0.37)\end{array}$ & $\begin{array}{l}0.305 \\
(1.16)\end{array}$ & $\begin{array}{l}0.222 \\
(0.99)\end{array}$ & $\begin{array}{l}-0.052 \\
(-0.22)\end{array}$ \\
\hline Call center and customer contact & $\begin{array}{l}-0.126 \\
(-0.53)\end{array}$ & $\begin{array}{l}0.166 \\
(0.53)\end{array}$ & $\begin{array}{l}-0.210 \\
(-0.53)\end{array}$ & $\begin{array}{l}-0.279 \\
(-0.84)\end{array}$ & $\begin{array}{l}-0.010 \\
(-0.03)\end{array}$ \\
\hline Design & $\begin{array}{l}-0.045 \\
(-0.13)\end{array}$ & $\begin{array}{l}0.090 \\
(0.16)\end{array}$ & $\begin{array}{l}-0.139 \\
(-0.31)\end{array}$ & $\begin{array}{l}-0.165 \\
(-0.36)\end{array}$ & $\begin{array}{l}0.148 \\
(0.24)\end{array}$ \\
\hline Engineering services & $\begin{array}{l}0.301 \\
(1.25)\end{array}$ & $\begin{array}{l}0.278 \\
(0.94)\end{array}$ & $\begin{array}{l}0.418 \\
(0.77)\end{array}$ & $\begin{array}{l}0.434 \\
(1.14)\end{array}$ & $\begin{array}{l}0.074 \\
(0.22)\end{array}$ \\
\hline Finance and accounting & $\begin{array}{c}0.636^{* *} \\
(2.55)\end{array}$ & $\begin{array}{l}0.790 * * \\
(2.34)\end{array}$ & $\begin{array}{l}0.747^{*} \\
(1.72)\end{array}$ & $\begin{array}{l}0.301 \\
(0.82)\end{array}$ & $\begin{array}{c}1.030^{* * *} \\
(2.87)\end{array}$ \\
\hline Human resources & $\begin{array}{c}0.831^{*} \\
(1.89)\end{array}$ & $\begin{array}{c}0.877^{*} \\
(1.68)\end{array}$ & $\begin{array}{l}0.822 \\
(0.95)\end{array}$ & $\begin{array}{l}0.377 \\
(0.58)\end{array}$ & $\begin{array}{c}1.250 * * \\
(2.21)\end{array}$ \\
\hline Information technology & $\begin{array}{l}0.161 \\
(0.78)\end{array}$ & $\begin{array}{l}0.105 \\
(0.39)\end{array}$ & $\begin{array}{l}0.572 \\
(1.42)\end{array}$ & $\begin{array}{l}0.160 \\
(0.48)\end{array}$ & $\begin{array}{l}0.040 \\
(0.14)\end{array}$ \\
\hline Knowledge services & $\begin{array}{l}0.128 \\
(0.43)\end{array}$ & $\begin{array}{l}-0.315 \\
(-0.68)\end{array}$ & $\begin{array}{l}0.736 \\
(1.43)\end{array}$ & $\begin{array}{l}-0.174 \\
(-0.39)\end{array}$ & $\begin{array}{l}0.427 \\
(0.98)\end{array}$ \\
\hline Legal services & $\begin{array}{l}-0.078 \\
(-0.10)\end{array}$ & $\begin{array}{c}-4.340 * * * \\
(-14.23)\end{array}$ & $\begin{array}{c}5.449 * * * \\
(10.96)\end{array}$ & $\begin{array}{l}0.307 \\
(0.36)\end{array}$ & $\begin{array}{c}-4.532 * * * \\
(-9.60)\end{array}$ \\
\hline Marketing and sales & $\begin{array}{l}0.349 \\
(1.11)\end{array}$ & $\begin{array}{l}0.397 \\
(1.14)\end{array}$ & $\begin{array}{l}-0.157 \\
(-0.22)\end{array}$ & $\begin{array}{l}0.266 \\
(0.66)\end{array}$ & $\begin{array}{l}0.122 \\
(0.20)\end{array}$ \\
\hline Other & $\begin{array}{l}-0.111 \\
(-0.23)\end{array}$ & $\begin{array}{l}0.461 \\
(0.49)\end{array}$ & $\begin{array}{l}-0.041 \\
(-0.07)\end{array}$ & $\begin{array}{c}-5.164 * * * \\
(-11.80)\end{array}$ & $\begin{array}{l}0.513 \\
(0.79)\end{array}$ \\
\hline Procurement & $\begin{array}{l}0.199 \\
(0.54)\end{array}$ & $\begin{array}{l}0.098 \\
(0.22)\end{array}$ & $\begin{array}{l}0.814 \\
(1.07)\end{array}$ & $\begin{array}{l}-0.096 \\
(-0.20)\end{array}$ & $\begin{array}{l}0.495 \\
(0.75)\end{array}$ \\
\hline Research and development & $\begin{array}{l}0.903 * \\
(1.95)\end{array}$ & $\begin{array}{c}1.488^{* *} \\
(2.39)\end{array}$ & $\begin{array}{l}0.312 \\
(0.47)\end{array}$ & $\begin{array}{l}1.106 \\
(1.55)\end{array}$ & $\begin{array}{l}0.743 \\
(1.17)\end{array}$ \\
\hline
\end{tabular}




\begin{tabular}{|c|c|c|c|c|c|}
\hline \multirow[t]{2}{*}{ Constant Cut 1} & $1.362 * *$ & $2.241 * * *$ & $1.481 *$ & 1.005 & 1.091 \\
\hline & $(2.55)$ & (3.13) & $(1.68)$ & $(1.41)$ & $(1.16)$ \\
\hline \multirow[t]{2}{*}{ Constant Cut 2} & $1.462 * * *$ & $2.350 * * *$ & $1.582 *$ & 1.117 & 1.183 \\
\hline & $(2.74)$ & $(3.27)$ & $(1.80)$ & $(1.57)$ & $(1.26)$ \\
\hline No. of observations & 486 & 303 & 183 & 267 & 219 \\
\hline Chi Square & $86.081 * * *$ & $927.129 * * *$ & $441.571 * * *$ & $956.268 * * *$ & $387.172 * * *$ \\
\hline Pseudo R-Square & 0.125 & 0.155 & 0.150 & 0.130 & 0.160 \\
\hline
\end{tabular}

Please note: $*$ if $\mathrm{p}<0.10, * *$ if $\mathrm{p}<0.05 ; * * *$ if $\mathrm{p}<0.01 . \mathrm{Z}$-statistics between brackets 
Table 8: Results of the robust Ordered Probit models (dependent variable: Entry mode hierarchy).

\begin{tabular}{|c|c|c|c|c|}
\hline & Column (1) & Column (2) & Column (3) & Column (4) \\
\hline Variables & High Cultural distance & Low Cultural distance & High Political Stability & Low Political Stability \\
\hline Business functions modularity & $\begin{array}{l}-0.113 \\
(-1.19)\end{array}$ & $\begin{array}{c}-0.164 * * \\
(-2.14)\end{array}$ & $\begin{array}{c}-0.490 * * \\
(-2.29)\end{array}$ & $\begin{array}{l}-0.074 \\
(-1.19)\end{array}$ \\
\hline Functional fine-slicing & $\begin{array}{c}-0.660 * * * \\
(-2.99)\end{array}$ & $\begin{array}{c}-0.491 * * * \\
(-2.73)\end{array}$ & $\begin{array}{l}-0.740 \\
(-1.63)\end{array}$ & $\begin{array}{c}-0.543 * * * \\
(-3.61)\end{array}$ \\
\hline Offshoring Experience & $\begin{array}{c}0.516^{* *} \\
(2.21)\end{array}$ & $\begin{array}{l}0.248 \\
(1.37)\end{array}$ & $\begin{array}{c}2.028 * * * \\
(4.33)\end{array}$ & $\begin{array}{l}0.131 \\
(0.83)\end{array}$ \\
\hline Firm Size & $\begin{array}{l}0.065 \\
(1.64)\end{array}$ & $\begin{array}{l}-0.050 \\
(-1.36)\end{array}$ & $\begin{array}{l}-0.038 \\
(-0.47)\end{array}$ & $\begin{array}{l}0.021 \\
(0.70)\end{array}$ \\
\hline Host Political Stability & $\begin{array}{l}0.011 \\
(1.09)\end{array}$ & $\begin{array}{l}0.012 \\
(1.11)\end{array}$ & $\begin{array}{l}-0.006 \\
(-0.28)\end{array}$ & $\begin{array}{l}-0.041^{*} \\
(-1.95)\end{array}$ \\
\hline Host Market Attractiveness & $\begin{array}{l}0.009 \\
(1.31)\end{array}$ & $\begin{array}{l}-0.009 \\
(-1.11)\end{array}$ & $\begin{array}{l}-0.002 \\
(-0.13)\end{array}$ & $\begin{array}{l}0.011^{*} \\
(1.69)\end{array}$ \\
\hline Host Human Resources & $\begin{array}{l}-0.004 \\
(-0.66)\end{array}$ & $\begin{array}{l}0.005 \\
(0.55)\end{array}$ & $\begin{array}{c}-0.036 * * * \\
(-3.45)\end{array}$ & $\begin{array}{l}0.010 \\
(1.42)\end{array}$ \\
\hline Host Low Labor Cost & $\begin{array}{l}-0.009 \\
(-0.99)\end{array}$ & $\begin{array}{l}-0.005 \\
(-0.52)\end{array}$ & $\begin{array}{l}-0.021 \\
(-1.35)\end{array}$ & $\begin{array}{l}0.000 \\
(0.03)\end{array}$ \\
\hline Home USA & $\begin{array}{l}-0.325 \\
(-1.35)\end{array}$ & $\begin{array}{l}-0.321 \\
(-1.48)\end{array}$ & $\begin{array}{l}-0.466 \\
(-0.93)\end{array}$ & $\begin{array}{l}-0.189 \\
(-1.13)\end{array}$ \\
\hline Cultural Distance & $\begin{array}{c}0.413 * * * \\
(2.59)\end{array}$ & $\begin{array}{l}0.216 \\
(1.00)\end{array}$ & $\begin{array}{c}0.534 * * * \\
(3.02)\end{array}$ & $\begin{array}{c}0.172 * \\
(1.87)\end{array}$ \\
\hline Offshoring Age & $\begin{array}{l}0.016 \\
(0.74)\end{array}$ & $\begin{array}{c}0.069 * * * \\
(2.85)\end{array}$ & $\begin{array}{c}0.381 * * * \\
(5.99)\end{array}$ & $\begin{array}{l}-0.004 \\
(-0.25)\end{array}$ \\
\hline Market-seeking & $\begin{array}{c}0.219 * * * \\
(2.58)\end{array}$ & $\begin{array}{c}0.157 * * \\
(2.19)\end{array}$ & $\begin{array}{l}0.012 \\
(0.06)\end{array}$ & $\begin{array}{c}0.175 * * * \\
(2.85)\end{array}$ \\
\hline Efficiency-seeking & $\begin{array}{l}-0.044 \\
(-0.52)\end{array}$ & $\begin{array}{l}-0.058 \\
(-0.78)\end{array}$ & $\begin{array}{c}-0.383 * * \\
(-2.03)\end{array}$ & $\begin{array}{l}-0.051 \\
(-0.85)\end{array}$ \\
\hline Human-resource seeking & $\begin{array}{l}0.088 \\
(1.03)\end{array}$ & $\begin{array}{l}-0.084 \\
(-1.13)\end{array}$ & $\begin{array}{l}-0.017 \\
(-0.10)\end{array}$ & $\begin{array}{l}0.033 \\
(0.53)\end{array}$ \\
\hline $\begin{array}{l}\text { High Tech and Knowledge Intensive } \\
\text { Industries }\end{array}$ & $\begin{array}{l}-0.250 \\
(-0.97)\end{array}$ & $\begin{array}{l}0.225 \\
(1.07)\end{array}$ & $\begin{array}{l}0.564 \\
(0.92)\end{array}$ & $\begin{array}{l}-0.053 \\
(-0.32)\end{array}$ \\
\hline Call center and customer contact & $\begin{array}{c}-0.754 * * \\
(-2.23)\end{array}$ & $\begin{array}{l}0.306 \\
(0.88)\end{array}$ & $\begin{array}{l}-0.714 \\
(-1.03)\end{array}$ & $\begin{array}{l}0.074 \\
(0.28)\end{array}$ \\
\hline Design & $\begin{array}{l}-0.638 \\
(-1.31)\end{array}$ & $\begin{array}{l}0.448 \\
(0.84)\end{array}$ & $\begin{array}{l}0.024 \\
(0.03)\end{array}$ & $\begin{array}{l}0.146 \\
(0.38)\end{array}$ \\
\hline Engineering services & $\begin{array}{l}-0.091 \\
(-0.23)\end{array}$ & $\begin{array}{l}0.583 \\
(1.64)\end{array}$ & $\begin{array}{l}1.537 * \\
(1.81)\end{array}$ & $\begin{array}{l}0.193 \\
(0.67)\end{array}$ \\
\hline Finance and accounting & $\begin{array}{l}0.498 \\
(1.13)\end{array}$ & $\begin{array}{c}0.829 * * \\
(2.52)\end{array}$ & $\begin{array}{l}0.900 \\
(1.10)\end{array}$ & $\begin{array}{c}0.756^{* * * *} \\
(2.72)\end{array}$ \\
\hline Human resources & $\begin{array}{l}0.269 \\
(0.28)\end{array}$ & $\begin{array}{l}1.013^{*} \\
(1.90)\end{array}$ & $\begin{array}{l}-2.082 \\
(-1.60)\end{array}$ & $\begin{array}{c}1.233 * * \\
(2.54)\end{array}$ \\
\hline Information technology & $\begin{array}{l}0.031 \\
(0.09)\end{array}$ & $\begin{array}{l}0.263 \\
(0.92)\end{array}$ & $\begin{array}{l}0.952 \\
(1.48)\end{array}$ & $\begin{array}{l}0.141 \\
(0.60)\end{array}$ \\
\hline Knowledge services & $\begin{array}{l}0.369 \\
(0.70)\end{array}$ & $\begin{array}{l}0.244 \\
(0.63)\end{array}$ & $\begin{array}{l}1.486 \\
(1.63)\end{array}$ & $\begin{array}{l}-0.014 \\
(-0.04)\end{array}$ \\
\hline Legal services & $\begin{array}{l}-0.029 \\
(-0.03)\end{array}$ & $\begin{array}{c}-3.636 * * * \\
(-9.32)\end{array}$ & $\begin{array}{c}0.000 \\
(.)\end{array}$ & $\begin{array}{l}0.017 \\
(0.02)\end{array}$ \\
\hline Marketing and sales & $\begin{array}{l}0.430 \\
(0.78)\end{array}$ & $\begin{array}{l}0.200 \\
(0.47)\end{array}$ & $\begin{array}{l}1.558 \\
(1.59)\end{array}$ & $\begin{array}{l}0.412 \\
(1.14)\end{array}$ \\
\hline Other & $\begin{array}{l}-0.392 \\
(-0.64)\end{array}$ & $\begin{array}{l}0.388 \\
(0.51)\end{array}$ & $\begin{array}{c}3.480 * * * \\
(2.75)\end{array}$ & $\begin{array}{l}-0.161 \\
(-0.26)\end{array}$ \\
\hline Procurement & $\begin{array}{l}-0.370 \\
(-0.76)\end{array}$ & $\begin{array}{c}1.329 * * \\
(1.99)\end{array}$ & $\begin{array}{l}0.918 \\
(0.79)\end{array}$ & $\begin{array}{l}0.315 \\
(0.78)\end{array}$ \\
\hline Research and development & $\begin{array}{l}0.361 \\
(0.58)\end{array}$ & $\begin{array}{c}1.284 * * \\
(2.07)\end{array}$ & $\begin{array}{l}-0.197 \\
(-0.23)\end{array}$ & $\begin{array}{c}1.163^{* *} \\
(2.45)\end{array}$ \\
\hline
\end{tabular}




\begin{tabular}{|c|c|c|c|c|}
\hline \multirow[t]{2}{*}{ Constant Cut 1} & $2.825 * * *$ & 1.137 & $2.980 *$ & $1.403 *$ \\
\hline & $(2.79)$ & $(1.47)$ & $(1.76)$ & (1.94) \\
\hline \multirow[t]{2}{*}{ Constant Cut 2} & $3.010 * * *$ & 1.183 & $3.227 *$ & $1.499 * *$ \\
\hline & $(2.97)$ & $(1.53)$ & $(1.91)$ & $(2.07)$ \\
\hline No. of observations & 205 & 281 & 107 & 379 \\
\hline Chi Square & $44.799 * *$ & $521.770 * * *$ & $1960.372 * * *$ & $53.723 * * *$ \\
\hline Pseudo R-Square & 0.158 & 0.181 & 0.537 & 0.102 \\
\hline
\end{tabular}

Please note: $*$ if $\mathrm{p}<0.10, * *$ if $\mathrm{p}<0.05 ; * * *$ if $\mathrm{p}<0.01$. Z-statistics between brackets 


\section{References}

Albertoni, F. \& Elia S. (2014). The global sourcing of business services: evidence from the Offshoring Research Network survey. Journal of Industrial and Business Economics, 41(2), 131-146

Albertoni, F., Elia, S., Massini, S., \& Piscitello, L. (2017). The Reshoring of Business Services: Reaction to Failure or Persistent Strategy? Journal of World Business, 52, 417-430.

Alchian, A. A., \& Demsetz, H. (1972). Production, information costs, and economic organization. The American Economic Review, 62, 777-795.

Anderson, V., \& Pereira, V. (2017). IHRD and Offshore Outsourcing. In T. Garavan, A. McCarthy, \& R. Carbery (Eds.), Handbook of International Human Resource Development. Context, Processes and People. Cheltenham, UK: Edward Elgar.

Arrow, K. (1974). The Limits of Organization. New York: Norton.

Ashok, M., Narula, R., \& Martinez-Noya, A. (2014). End-User Collaboration for Process Innovation in Services: The Role of Internal Resources. Discussion Paper Number: JHD-2014-03, Henley Business School University of Reading, UK.

Asmussen C.G., Larsen M.M., \& Pedersen T. (2016). Organizational Adaptation in Offshoring: The Relative Performance of Home- and Host-Based Learning Strategies. Organization Science, 27, 911-928.

Baldwin, C. Y. (2008). Where do transactions come from? Modularity, transactions, and the boundaries of firms. Industrial and Corporate Change, 17, 155-195.

Baldwin, C. Y., \& Clark, K. B. (1997). Managing in an age of modularity. Harvard Business Review, $75,84-93$.

Baldwin, C. Y., \& Clark, K. B. (2000). Design Rules, Volume 1, The Power of Modularity. Cambridge, MA: MIT Press.

Baldwin, C. Y., \& Clark, K. B. (2006). Modularity in the Design of Complex Engineering Systems. In A. Minai, D. Braha, \& Y. B. Yam (Eds.), Complex Engineered Systems: Science Meets Technology. New York: Springer.

Barney, J. B. (1991). Firm Resources and Sustained Competitive Advantage. Journal of Management, $17,99-120$.

Barney, J. B. (1996). The resource-based theory of the firm. Organization Science, 7, 469-496.

Basile, R., Giunta, A. \& Nugent, J. B. (2003). The foreign expansion of Italian manufacturing firms in the nineties: an ordered probit analysis. Review of Industrial Organization, 23, 1-24.

Bask, A., Lipponen, M., Rajahonka, M., \& Tinnilä, M. (2010). The concept of modularity: diffusion from manufacturing to service production. Journal of Manufacturing Technology Management, $21,355-375$.

Benito, G. R., Petersen, B., \& Welch, L. S. (2009). Towards more realistic conceptualisations of foreign operation modes. Journal of International Business Studies, 40(9), 1455-1470. 
Brouthers, K. (2002). Institutional, cultural and transaction cost influences on entry mode choice and performance. Journal of international business studies, 33, 203 - 221.

Brouthers, K.D., Brouthers, L.E., \& Werner, S. (2008). Resource-based advantages in an international context. Journal of Management, 34, 189-217.

Brouthers, K. (2013). A retrospective on: Institutional, cultural and transaction cost influences on entry mode choice and performance. Journal of international business studies, 44, $14-22$.

Brusoni, S. (2005). The limits to specialization: problem solving and coordination in 'modular networks'. Organization Studies, 26, 1885-1907.

Brusoni, S., \& Prencipe, A. (2001). Unpacking the Black Box of Modularity: Technologies, Products and Organizations. Industrial and Corporate Change, 10, 179-205.

Brusoni, S., Prencipe A., \& Pavitt, K. (2001). Knowledge specialization, organizational coupling, and the boundaries of the firm: Why do firms know more than they make? Administrative Science Quarterly, 46, 597-621.

Buckley, P.J., \& Casson, M. C. (1976). The Future of Multinational Enterprise. London: The Macmillan Press.

Buckley, P.J., Munjal, S., Enderwick, P., Forsans, N. (2017). The role of country alliances in reducing the transaction costs of internationalisation: evidence from Indian multinational enterprises. Cambridge Journal of Economics, 41(3), 807-828.

Cabigiosu, A. \& Camuffo, A. (2012). Beyond the "mirroring" hypothesis: Product modularity and interorganizational relations in the air conditioning industry. Organization Science, 23, 686-703.

Cacciatori, E., \& Jacobides, M. G. (2005). The dynamic limits of specialization: vertical integration reconsidered. Organization Studies, 26, 1851-1883.

Campagnolo, D., \& Camuffo, A. (2010). The concept of modularity in management studies: a literature review. International Journal of Management Reviews, 12, 259-283.

Cantwell, J. \& Narula R. (2001). The eclectic paradigm in the global economy. International Journal of the Economics of Business, 8, 155-172.

Cantwell, J. A., \& Santangelo, G.D. (2000). Capitalism, profits and innovation in the new technoeconomic paradigm. Journal of Evolutionary Economics, 10, 131-157.

Castañer, X., Mulotte, L., Dussauge, P., \& Garrette, B. (2014). Governance mode vs. governance fit? Performance implications of make-or-ally choices for product innovation in the worldwide aircraft industry, 1942-2000. Strategic Management Journal, 35, 1386-1397.

Chang, S. J., Chung, J., \& Moon, J. J. (2013). When do wholly owned subsidiaries perform better than joint ventures?. Strategic Management Journal, 34(3), 317-337.

Coase, R.H. (1937). The nature of the firm. Economica, 4, 386-405.

Colfer, L. J., \& Baldwin, C. Y. (2016). The mirroring hypothesis: theory, evidence, and exceptions. Industrial and Corporate Change, 0, 1-30. 
Den Hertog, P. (2000). Knowledge intensive business services as co-producers of innovation. International Journal of Innovation Management, 4, 491-528.

Dibbern, J., Winkler, J., \& Heinzl, A. (2008). Explaining variations in client extra costs between software projects offshored to India. MIS Quarterly, 32, 333-366.

Dunning, J. H. (1993). Multinational enterprises and the global economy. Wokingham, Berkshire: Addison Wesley.

Elia S., Caniato F., Luzzini D., \& Piscitello L. (2014). Governance choice in global sourcing of services: the impact on service quality and cost saving performance. Global Strategy Journal, 4, 181-199.

Eurostat-OECD (2007). Science, Technology and Innovation in Europe. Brussels, Belgium: Eurostat Pocketbooks.

Furlan, A., Cabigiosu, A. \& Camuffo, A. (2014). When the mirror gets misted up: Modularity and technological change. Strategic Management Journal, 35, 789-807.

Gawer, A. \& N. Phillips (2013). Institutional work as logics shift: the case of Intel's transformation to platform leader. Organization Studies, 34, 1035-1071.

Gooris J. \& Peeters C. (2016). Fragmenting global business processes: A protection for proprietary information. Journal of International Business Studies, 47, 535-562.

Granstrand, O., Patel P., \& Pavitt, K., (1997). Multi-technology corporations: why they have distributed rather than distinctive core competences. California Management Review, 39, 8-25.

Greene, W. (2010). Testing hypotheses about interaction terms in nonlinear models. Economics Letters, 107, 291-296.

Hätönen, J., \& Eriksson, T. (2009). 30+ years of research and practice of outsourcing - Exploring the past and anticipating the future. Journal of International Management, 15, 142-155.

Hennart, J. F. (1988). A transaction cost theory of equity joint ventures. Strategic Management Journal, 9, 361-374.

Hennart, J. F. (1989). Can the New Forms of Investment Substitute for the Old Forms? A Transaction Costs Perspective. Journal of International Business Studies, 20, 211-33.

Hennart, J.-F., \& Slangen, A. H. L. (2014). Yes, we really do need more entry mode studies. Journal of International Business Studies, 46, 114-122.

Hofstede, G. (2001). Culture's Consequences: Comparing Values, Behaviors, Institutions, and Organizations Across Nations, 2nd ed. Thousand Oaks, CA: Sage.

Johanson, J., \& Vahlne, J.-E. (1977). The Internationalization Process of the Firm: a Model of Knowledge Development and Increasing Foreign Market Commitments. Journal of International Business Studies, 8, 23-32.

Kenney, M., Massini, S. \& Murtha, T.P. (2009). Offshoring administrative and technical work: New fields for understanding the global enterprise. Journal of International Business Studies, 40(6), $887-900$ 
Kogut, B., \& Singh, H. (1988). The effect of national culture on the choice of entry mode. Journal of International Business Studies, 19, 411-432.

Kogut, B. \& Zander, U. (1992). Knowledge of the firm, combinative capabilities, and the replication of technology. Organization science, 3, 383-397.

Kotabe, M., Parente, R., \& Murray, J. Y. (2007). Antecedents and outcomes of modular production in the Brazilian automobile industry: A grounded theory approach. Journal of International Business Studies, 38, 84-106.

Langlois, R. N. (2002). Modularity in technology and organization. Journal of Economic Behavior and Organization, 49, 19-37.

Langlois, R. N., \& Robertson, P. L. (1992). Networks and innovation in a modular system: Lessons from the microcomputer and stereo component industries. Research Policy, 21, 297-313.

Larsen, M.M. (2016). Failing to Estimate the Costs of Offshoring: A Study on Process Performance. International Business Review, 25, 307-318.

Larsen, M.M, Manning, S., \& Pedersen, T. (2013). Uncovering the hidden costs of offshoring: The interplay of complexity, organizational design, and experience. Strategic Management Journal, $34,533-552$.

Lew, Y.K., Sinkovics, R.R., Yamin, M. \& Khan, Z. (2016). Trans-specialization understanding in international technology alliances: The influence of cultural distance. Journal of International Business Studies, 47, 577-594.

Lewin A.Y., \& Peeters C. (2006). Offshoring administrative and technical work: business hype or the onset of fundamental strategic and organizational transformation? Long Range Planning, 39, 221-239.

Lewin, A.Y., Massini, S., \& Peeters, C. (2009). Why are companies offshoring innovation? The emerging global race for talent. Journal of International Business Studies, 40, 901-925.

MacDuffie, J. P. (2013). Modularity-as-Property, Modularization-as-Process, and 'Modularity'-asFrame: Product Architecture Initiatives in the Global Auto Industry. Global Strategy Journal, 3, $8-40$.

MacDermott, G., Mudambi, R., \& Parente, R. (2013). Strategic modularity and the architecture of multinational firm. Global Strategy Journal, 3, 1-7.

MacDuffie, J. P. (2013). Modularity-as-Property, Modularization-as-Process, and 'Modularity'-asFrame: Product Architecture Initiatives in the Global Auto Industry. Global Strategy Journal, 3, $8-40$.

Madhok, A. (1997). Cost, value and foreign market entry mode: the transaction and the firm. Strategic Management Journal, 18, 39-61.

Madhok, A. (2002). Reassessing the Fundamentals and Beyond: Ronald Coase, the Transaction Cost and Resource-based Theories of the Firm, and the Institutional Structure of Production. Strategic Management Journal, 23, 535-550. 
Manning, S., Massini, S. \& Lewin, A.Y. (2008). A dynamic perspective on next-generation offshoring: The global sourcing of science and engineering talent. Academy of Management Perspectives, 22(3), 35-54.

Manning S., Massini S., Peeters C., \& Lewin A.Y. (2012). The global co-evolution of firm boundaries: Commoditization, capabilities, and paths dependencies. In Proceedings of the Academy of International Business meeting, Washington D.C., 30 June - 3 July 2012.

Marengo, L., \& Dosi G. (2005). Division of Labor, Organizational Coordination and Market Mechanisms in Collective Problem-Solving. Journal of Economic Behavior and Organization, 58, 303-326.

Meyer, K, Wright M, \& Pruthi S. (2009). Managing knowledge in foreign entry strategies: A resource-based analysis. Strategic Management Journal, 30, 557-574.

Miles, I. (1993). Services in the new industrial economy. Futures, 25, 653-72.

Miozzo, M., \& Grimshaw, D. (2005). Modularity and innovation in knowledge-intensive business services: IT outsourcing in Germany and the UK. Research Policy, 34, 1419- 1439.

Monteverde, K., (1995). Technical dialog as an incentive for vertical integration in the semiconductor industry. Management Science, 41, 1624-1638.

Mudambi, S. M., \& Tallman S. (2010). Make, Buy or Ally? Theoretical Perspectives on Knowledge Process Outsourcing Through Alliances. Journal of Management Studies, 47, 1434-1456.

Narula, R. (2001). Choosing between internal and non-internal R\&D activities: some technological and economic factors. Technology Analysis \& Strategic Management, 13(3), 365-387.

Narula, R. (2014). Exploring the paradox of competence-creating subsidiaries: balancing bandwidth and dispersion in MNEs. Long Range Planning, 47, 4-15.

Narula, R. \& Hagedoorn, J. (1999). Innovating through strategic alliances: moving towards international partnerships and contractual agreements. Technovation, 19, 283-294.

Narula, R., \& Martinez-Noya A. (2015). International R\&D alliances by firms: Origins and development. The Handbook of Global Science, Technology, and Innovation. In D. Archibugi \& A. Filippetti (Eds.), The Handbook of Global Science, Technology, and Innovation. WileyBlackwell.

Narula, R., \& Verbeke, A. (2015). Making internalization theory good for practice: The essence of Alan Rugman's contributions to international business. Journal of World Business, 50(4), 612622.

Nickerson, J. A., \& Zenger T. R. (2004), A knowledge-based theory of the firm-the problem-solving perspective. Organization Science, 15, 617-632.

Norton, E., Wang, H. \& Ai, C. (2004). Computing interaction effects and standard errors in logit and probit models. Stata Journal, 4, 154-167.

Oshri, I., Kotlarsky, J., \& Willcocks, L. P. (2015). The Handbook of Global Outsourcing and Offshoring. Palgrave MacMillan, London. 
Parente, R.C., Baack, D.W., \& Hahn, E.D. (2011). The effect of supplier integration, modular production, and cultural distance on new product development: A dynamic capabilities approach. Journal of International Management, 17, 278-290.

Parida, V., Wincenta, J., \& Oghazid, P. (2016). Transaction costs theory and coordinated safeguards investment in R\&D offshoring. Journal of Business Research, 69, 1823-1828.

Penrose, E.T. (1959). The Theory of the Growth of the Firm. New York: Oxford University Press.

Pereira, V., and Malik, A. (2015). Human Capital Management in the Indian IT/BPO Industry. London: Palgrave Macmillan, London.

Pereira, V., Munjal, S. and Ishizaka A. (2017). Outsourcing and Offshoring Decision Making and its Implications for the firm. Journal of Business Research, forthcoming.

Podsakoff, P. M., MacKenzie, S. B., Lee, J. Y., \& Podsakoff, N. P. (2003). Common method biases in behavioral research: A critical review of the literature and recommended remedies. Journal of Applied Psychology, 88, 879-903.

Reitzig, M., \& Wagner, S. (2010). The hidden costs of outsourcing: Evidence from patent data. Strategic Management Journal, 31, 1183-1201.

Rugman, A. M. (1980). Internalization as a general theory of foreign direct investment: A re-appraisal of the literature. Review of World Economics, 116, 365-379.

Rugman, A. M. (1986). New Theories of the Multinational Enterprise: An assessment of Internalization Theory. Bulletin of Economic Research, 2, 101-118.

Sanchez, R. (1999). Modular architectures in the marketing process. Journal of Marketing, 63, 92111.

Teece, D.J. (1996). Firm organization, industrial structure and technological innovation. Journal of Economic Behaviour and Organisation, 31, 193-224.

Tether B.S., \& Tajar A. (2008). Beyond industry-university links: Sourcing knowledge for innovation from consultants, private research organizations and the public science-base. Research Policy, 37, 1079-1095.

Voss, C. A., \& Hsuan, J. (2009). Service architecture and modularity. Decision Sciences, 40, 541569.

Williamson, O.E. (1975). Markets and Hierarchies: Analysis and Antitrust Implications. New York: Free Press. 


\section{Notes}

i The ORN counts 13 partner universities and business schools belonging to the following countries: Australia, Belgium, Brazil, China, Denmark, Germany, France, Italy, Japan, Korea, Netherlands, United Kingdom, and Spain.

ii As regards the Common Method Bias, it is worth noting that the variables employed in our analysis are located in different parts of the questionnaire and that anonymity has been guaranteed to respondents (Podsakoff et al., 2003). In addition, the Harman's single factor test (Podsakoff et al., 2003) showed that the portion of total variance accounted for by each single factor is very limited, thus suggesting that common method bias is not a serious concern with our dataset. iii This variable has been reverse coded by giving the scores a negative sign, since the original items display high values when labor costs are high. By employing the variable with negative sign, we associate high scores to countries with low cost of labor.

${ }^{\text {iv }}$ We do not consider the natural-resource seeking driver as the focus of our paper is on the offshoring of business services.

v The OECD (2007) classifies as "Knowledge Intensive Services" the following industries: Water transport, Air transport, Post and telecommunications, Financial intermediation, Insurance and pension funding, Activities auxiliary to financial intermediation, Real estate activities, Renting of machinery and equipment without operator and of personal and household goods, Computer and related activities, Research and development, Other business activities, Education, Health and social work, Recreational, cultural and sporting activities. The "High Tech Manufacturing Industries" are Aerospace, Computers, office machinery, Electronics-communications, Pharmaceuticals, Scientific instruments, while the "Medium-High tech industries" are Motor vehicles, Electrical machinery, Chemicals, Other transport equipment, Non-electrical machinery. The "Less Knowledge Intensive Service Industries" are: Sale, maintenance and repair of motor vehicles and motorcycles; retail sale of automotive fuel, Wholesale trade and commission trade, except of motor vehicles and motorcycles, Retail trade, except of motor vehicles and motorcycles; repair of personal and household goods Hotels and restaurants, Land transport; transport via pipelines, Supporting and auxiliary transport activities; activities of travel agencies, Public administration and defense; compulsory social security, Sewage and refuse disposal, sanitation and similar activities, Activities of membership organization n.e.c., Other service activities, Private households with employed persons, Extra-territorial organizations and bodies. Finally, the "Medium-Low Tech Manufacturing Industries" include: Rubber and plastic products, Shipbuilding, Other manufacturing, Non-ferrous metals, Non-metallic mineral products, Fabricated metal products, Petroleum refining, Ferrous metals; conversely, the "Low-tech manufacturing industries" are: Paper printing, Textile and clothing, Food, beverages, and tobacco, Wood and furniture. 